Tunipaloja rajapinnoilla? : Tampereen yliopiston legitimiteettikamppailut hybridissä mediatilassa

\title{
Sihvonen, Tanja
}

2020-12-17

Sihvonen , T , Koskela , M \& Laaksonen , S-M 2020 , ' Tunipaloja rajapinnoilla? Tampereen yliopiston legitimiteettikamppailut hybridissä mediatilassa ' , Media \& viestintä : kulttuurin ja yhteiskunnan tutkimuksen lehti , Vuosikerta. 43 , Nro 4 , Sivut 272-302 . https://doi.org/10.23983/mv.100617

http://hdl.handle.net/10138/323632

https://doi.org/10.23983/mv.100617

cc_public_domain

publishedVersion

Downloaded from Helda, University of Helsinki institutional repository.

This is an electronic reprint of the original article.

This reprint may differ from the original in pagination and typographic detail.

Please cite the original version. 


\title{
Artikkeli
}

\section{Tunipaloja rajapinnoilla?}

\section{Tampereen yliopiston legitimiteettikamppailut hybridissä mediatilassa}

\begin{abstract}
Tässä artikkelissa analysoimme Tampereen yliopiston organisaatiouudistukseen ja erityisesti sen uuteen brändi- ja viestintästrategiaan kytkeytyviä legitimiteettikamppailuja hybridissä mediatilassa. Aineistona käytämme sekä journalistisesta mediasta $(n=39)$ että sosiaalisesta mediasta $(n=9303)$ kerättyjä puheenvuoroja. Käsitteellistämme Tampereen yliopistouudistusta koskevat huolet uuden muotoisen yliopiston legitimiteettiä koskevina argumentteina ja keskusteluina. Niiden avulla tutkimme, millä tavoin uudistettua Tampereen yliopistoa pyrittiin legitimoimaan ja delegitimoimaan median ja sosiaalisen median julkisissa keskusteluissa keväällä 2020 ja millaista vuorovaikutusta hybridin mediatilan eri mediamuotojen välillä voidaan havaita. Analyysimme eri mediamuodoissa esiintyvistä legitimiteetin arvioista osoittaa, miten mediatilan monimuotoistuminen tuottaa ongelmia monikohteiselle sidosryhmäviestinnälle, jossa organisaation legitimiteettiä pyritään muutostilanteessa rakentamaan. Tuloksemme korostavat viestinnän ja viestintätyylien merkitystä legitimaatiossa: kamppailujen keskiössä on yliopiston uudenlainen, yritysmaailmasta ammentava viestintätyyli, jonka metaforat päätyvät verkkokeskusteluissa kritiikin työvälineiksi.
\end{abstract}

AVAINSANAT: yliopisto, legitimiteetti, sosiaalinen media, journalismi, hybridi mediatila

V uoden 2019 alussa aloittanut uusi Tampereen yliopisto on ollut muutaman viime vuoden aikana taajaan julkisuudessa. Säätiöyliopiston perustamiseen liittyvät uutiset kertovat riidoista sen nimestä, tietojärjestelmistä, tiedonvälityksestä ja rahoituksesta, rehtorivalinnan epäselvyyksistä sekä uudesta johtosäännöstä, jonka katsottiin murentavan yliopiston autonomian ja josta tehtiin valitus eduskunnan oikeusasiamiehelle asti (Grönholm 2019). Media- ja viestinnäntutkimuksen kehyksessä kiinnostavaa on, että suuri osa Tampereen yliopistoa koskevista uutisista ja keskusteluista on keskittynyt sen uudenlaiseen viestintä- ja brändistrategiaan. Sen viestintälinja ja brändäystoimenpiteet ovat muutamaan otteeseen herättäneet niin suurta mielenkiintoa, että ne ovat nousseet aiheiksi jopa valtakunnan päälehteen (esim. Junkkari 2018; Harju 2018). Myös yliopiston hallituksen puheenjohtaja on joutunut julkisesti puuttu- 
maan tilanteeseen (esim. Keski-Heikkilä 2020b). Julkisuudessa erityisesti Tampereen yliopiston henkilöstön jäsenet, tutkijat, opettajat ja opiskelijat ovat kokeneet tilanteen vaikuttavan negatiivisesti yliopiston maineeseen ja julkisuuskuvaan. Näitä keskusteluja on käyty sosiaalisen median eri areenoilla, varsinkin Twitterissä. Etenkin yliopiston 19.4.2018 julkistettuun violettiin logoon, niin sanottuun tuninaamaan, kiteytyvä kamppailu symbolisesta näkyvyydestä tuo kiinnostavalla tavalla esiin yliopiston brändiviestinnän ja sitä kritisoivien sosiaalisen median keskustelujen välisiä näkemyseroja.

Tässä artikkelissa käsitteellistämme nämä huolet uuden muotoisen Tampereen yliopiston legitimiteettiä koskevina argumentteina ja keskusteluina, joiden esiintymistiheys nousi poikkeuksellisella tavalla vuoden 2020 alkupuolella (ks. kuvio 2). Legitimiteetti eli olemassaolon oikeutus (Suchman 1995, 574; Van Leeuwen 2007, 94) on yliopiston kaltaisille julkisen sektorin toimijoille erityisesti muutosten yhteydessä tärkeä sekä uskottavuuden että tulevaisuuden turvaamisen vuoksi. Pohdimme Tampereen yliopistoon liittyvää julkisuutta legitimiteetin näkökulmasta ja pyrimme ymmärtämään, mistä legitimiteettiin liittyvissä puheenvuoroissa on kyse. Osana näitä diskursseja tarkastelemme myös median roolia, sillä mediakeskustelussa nousee esiin paitsi yliopiston legitimiteettiä tukevaa sisältöä, myös nostoja, joiden kautta tuotetaan aktiivisesti delegitimaatiota.

Olemme tunnistaneet viestintätapahtumien osapuoliksi itse yliopisto-organisaation (viestintä- ja brändijohtaja tiimeineen), yliopiston johdon (rehtori), sidosryhmät (hallitus, omistajat), yliopistoyhteisön (henkilökunta, opiskelijat), yliopistoon liittyviä asioita käsittelevän journalismin sekä sosiaalisessa mediassa aktivoituvat keskustelijat edellä mainitut tahot mukaan lukien. Tutkimuksemme aineisto keskittyy näistä kahteen viimeksi mainittuun, eli uutta Tampereen yliopistoa käsitteleviin sosiaalisen median keskusteluihin ja journalismiin. Sosiaalisen median aineiston avulla tutkimme sitä, miten julkaisut, kommentit ja meemit tuottavat jaettua ymmärrystä yliopiston viestinnästä, siihen reagoimisesta ja sen mahdollistamasta vuorovaikutuksesta. Luotaamme Tampereen yliopiston legitimiteettiä koskevia keskusteluja sosiaalisessa mediassa hakusanojen tuninaama, tunipalo ja tampereuni kautta. Tarkastelemme näin hahmottuvaa verkkokeskustelun kenttää vuoden 2020 alussa ruohonjuuritason legitimaatiokamppailuna, joka kohdistuu Tampereen yliopiston viestintään, sitä määrittävään viestintästrategiaan sekä viestinnästä käytävään julkiseen keskusteluun, jonka keskeisenä perinteisenä kanavana toimii journalismi.

Tutkimuksemme toinen aineisto on kerätty Tampereen yliopistoa käsittelevästä journalismista. Taustoittaaksemme vuonna 2020 esiin nousseita viestintäkohuja ja legitimaatiokamppailua viittaamme lehtijuttuihin laajemmalla aikaperspektiivillä, ensimmäisistä vuonna 2018 julkaistuista jutuista alkaen. Käytämme tausta-aineistona myös yliopiston rehtorin lähettämiä sähköpostiviestejä, joihin tutkimusaineistossamme viitataan. Näin tutkimuksemme täydentää media-aineistojen kautta Kuuselan ja kumppaneiden (2019) raporttia työntekijöiden näkemyksistä yliopiston muutoksesta. Siinä missä mainitussa raportissa keskitytään Tampereen yliopiston henkilöstön kriittisiin näkemyksiin yliopiston johtamisjärjestelmästä ja itsehallinnosta (Kuusela ym. 2019), meidän tutkimuksemme näkökulma aiheeseen on mediakeskusteluissa ja niiden legi- 
timaatiota tuottavassa ja toisaalta murentavassa roolissa. Tutkimuksemme käsittelee näin sekä sosiaalisen median keskusteluissa että journalismissa ilmeneviä ristiriitaisia pyrkimyksiä yliopiston legitimiteetin rakentamiseen ja horjuttamiseen.

Yliopiston viestintästrategian ja samalla artikkelimme laaja taustakonteksti on paikannettavissa vuoden 2010 suureen yliopistouudistukseen ja sen jälkeiseen korkeakoulujen markkinaistumiseen (marketization, ks. Furedi 2010; Naidoo \& Jamieson 2005; Jessop 2017; Ylijoki 2020), joka näkyy erityisesti yliopistojen pyrkimyksessä rakentaa itsestään julkisuudessa tietynlaista brändiä (Chapleo 2011; Aula ym. 2015; Raipola 2019). Julkinen sektori on ollut Suomessa pitkään itsestään selvä ja kyseenalaistamaton, ja esimerkiksi yliopiston sivistystehtävä on pitkälle 2000-luvulle asti ollut riittävä oikeutus sen olemassaololle. Näin kuitenkaan ei enää ole, vaan suomalaiset yliopistot joutuvat kilpailemaan paitsi keskenään myös kansainvälisesti tutkimusrahoituksesta, hakijoista, tutkijoista ja toiminnan mahdollistavista resursseista. Yliopistojen brändinrakennuksen ja brändistä käytävien kamppailujen kautta päästään tarkastelemaan niitä ristiriitoja, jotka muovaavat paitsi yliopistoa toimintaympäristönä myös sen julkisuuskuvasta käytäviä keskusteluja (ks. Wæraas \& Solbakk 2009; Korpela \& Nevala 2020). Tutkimusasetelma on inspiroiva, sillä siinä aiemmin puhtaasti julkinen organisaatio (valtion tiliviraston asemassa toiminut yliopisto) perustelee toimintansa lähtökohtia kaupallisten organisaatioiden ehdoilla ja eri sidosryhmät, joista jotkut ovat yliopistokentässä uusia, arvioivat näiden perustelujen onnistumista kukin omista lähtökohdistaan.

Bitektinen ja Haackin (2015) mukaan organisaation legitimiteettiä arvioidaan yhteiskunnan eri tasoilla: esimerkiksi joukkoviestintä ja lainsäädäntökoneisto edustavat makrotasoa, mutta myös yksilöiden arviot ja jopa ei-auktoriteettiset toimijat - esimerkiksi anonyymit verkkokeskustelijat - vaikuttavat mikrotasolla organisaation legitimiteetin muodostumiseen.

Nykyisessä, hybridiksi kutsutussa mediatilassa näitä arviointeja esitetään eri mediamuodoissa, joiden eriävät logiikat ja toimintatavat sekoittuvat toisiinsa (Chadwick 2013; Ojala ym. 2019). Kun organisaatio käy läpi institutionaalista murrosta, legitimiteetin arvioinnit ovat erityisen tärkeässä roolissa sen validiteetin muodostumisessa. Legitimiteetin puute eli illegitimiteetti voi johtaa yhteisössä sosiaalisen järjestyksen vastustamiseen tai aktiiviseen muutoksen ajamiseen (Tost 2011, 687; Haack ym. 2014).

Näin hahmotellun teorian perusteella kysymme: 1) Millä tavoin uuden muotoista Tampereen yliopistoa pyrittiin legitimoimaan ja delegitimoimaan median ja sosiaalisen median julkisissa keskusteluissa keväällä 2020? 2) Minkälaista vuorovaikutusta hybridin mediatilan eri mediamuotojen välillä on legitimaatioprosessissa? Artikkelissa käymme ensin läpi legitimiteettiin liittyvää teoriataustaa viestinnän ja hybridin mediatilan näkökulmista. Sen jälkeen tarkastelemme yliopistojen muuttuvaa asemaa ja markkinaistumista niiden irtautuessa julkisen vallan piiristä. Esittelemme tutkimuksessamme käytetyn aineiston ja menetelmät, ja analysoimme sen jälkeen ensin journalistisen media-aineiston ja sitten sosiaalisesta mediasta kerätyn aineiston. Tarkastelemme aineiston esimerkkejä moraalisen, kognitiivisen ja pragmaattisen legitimaation näkökulmasta. Lopuksi vedämme analyysimme tulokset yhteen ja tuomme keskusteluun kokoavia näkökohtia Tampereen yliopiston legitimiteettikamppailujen eri vaiheista. 


\section{Legitimiteetti viestinnällisenä prosessina}

Legitimiteetti on käsite, jonka kautta organisaation yhteiskunnallista hyväksyntää, sen toimintaa ja toiminnan perusteluita voidaan teoreettisesti tarkastella eri konteksteissa. Suchmanin (1995) klassisen määritelmän mukaan legitimiteetissä on kyse yleisestä käsityksestä tai oletuksesta siitä, että organisaation toimenpiteet ovat haluttavia, oikeita tai sopivia tietyssä sosiaalisesti rakentuneessa normi-, arvo- tai uskomusjärjestelmässä. Legitimaatiota voidaan pitää organisaatioiden olemassaolon edellytyksenä (Tost 2011; Meyer \& Scott 1983). Jos legitimiteetti puuttuu eli toimija koetaan illegitiimiksi, tilanne tyypillisesti pakottaa organisaation reagoimaan ja muuttumaan.

Legitimiteettiä voidaan tarkastella pragmaattisena, moraalisena tai kognitiivisena kysymyksenä riippuen siitä, ovatko keskiössä yleisöjen mieltämä käytännön hyöty, moraaliset ja normatiiviset arvioinnit vai toiminnan ymmärrettävyys ja itsestäänselvyys (Suchman 1995). Periaatteellisella tasolla legitimiteetin voi saavuttaa silloin, kun organisaation toiminta ja viestintä ovat yhdenmukaisia vallitsevan kulttuurisen ympäristön ja normijärjestelmän kanssa (Suchman 1995; Deephouse \& Suchman 2008, 51). Jos taas organisaation sidosryhmät kokevat, että organisaatio on illegitiimi, vastarinnan todennäköisyys kasvaa (Tost 2011, 687; Haack ym. 2014). Tällöin legitimiteetin arviointi muuttuu kognitiivisesta ja passiivisesta kohti aktiivista, pragmaattista ja moraalista arviointia (Suchman 1995).

Legitimiteetti on siis vahvasti organisaation sidosryhmäsuhteissa rakentuva asia. Legitimiteettiarvioita tekevät periaatteessa kaikki yksittäiset sidosryhmän edustajat mikrotasolla (Bitektine 2011), mutta sosiaalisten prosessien kautta siitä muodostuu ja validoituu kollektiivinen arvio - käsitys toimijasta institutionalisoituu (Berger \& Luckmann 1966, 53; Bitektine \& Haack 2015, 53; Tost 2011). Tost (2011) jaottelee legitimaatioarvioiden dynamiikkaa pohjaten juuri yksilöiden toimintaan. Hänen mukaansa yksilölähtöisen legitimaation muodostuminen voidaan jaotella sosiaalipsykologisesta näkökulmasta kolmeen eri strategiaan: välineelliseen, suhteelliseen ja moraaliseen arviointiin (Tost 2011, 686). Suchmanin kategorisointeja mukaillen näissä strategioissa on kyse organisaation tuottamasta välineellisestä ja pragmaattisesta hyödystä, sosiaalisesta hyväksyttävyydestä yhteisössä sekä moraalisista arvioinneista. Moraalinen ja pragmaattinen legitimaatio rakentuvat diskursiivisesti (Suchman 1995, 585). Siksi subjektiivisten legitimaatioarvioiden sisältö sijoittuu usein juuri moraaliseen legitimaatioon (Tost 2011, 692).

Moraalisen legitimiteetin kiistat ovat kuitenkin usein yhteiskunnallisia keskusteluja, joissa myös organisaatio itse voi olla mukana. Tavallisimmin näissä kiistoissa arvioijan roolissa ovat perinteiset, auktoriteettiasemassa olevat makrotason arvioijat, kuten lainsäätäjät, tuomioistuimet ja media (Bitektine \& Haack 2015). Legitimiteetin tutkimus onkin keskittynyt juuri näihin toimijoihin, jotka nähdään legitimiteettiarviointeja validoivina instituutioina (emt.). Bitektine ja Haack (2015) kuitenkin huomauttavat, että myös toimijat, joilla ei ole selkeää auktoriteettiasemaa - esimerkiksi kansalaiset - voivat sanktioida organisaatioita diskursiivisen ja symbolisen toiminnan kautta julkisuutta hyödyntäen. Näin varsinkin, jos makrotason arvioinneissa on 
epäselvyyttä ja ristiriitoja tai sosiaaliset normit ovat muutoksessa, eikä legitimiteetistä vallitse yhteiskunnallista konsensusta. Huomionarvoista on lisäksi, että legitimiteettiä tuotetaan ja uusinnetaan organisaation sisällä, vuorovaikutuksessa ulkoisen legitimaatioprosessin kanssa (Drori \& Honig 2013). Arvioinneissa nousevat siis keskeiseen asemaan myös organisaation sisäiset sidosryhmät kuten työntekijät. Taulukossa 1 on esitetty lyhyesti legitimiteetin tyypit ja alatyypit, niiden määritelmät sekä yleisluonnehdinta siitä, miten kutakin legitimiteettityyppiä tuotetaan.

Taulukko 1. Legitimiteetin tyypit ja alatyypit määritelmineen.

\begin{tabular}{|c|c|c|}
\hline $\begin{array}{l}\text { Legitimiteetin } \\
\text { tyyppi }\end{array}$ & Määritelmä & Miten tuotetaan \\
\hline Moraalinen & $\begin{array}{l}\text { Perustuu siihen, että organisaatio edistää } \\
\text { moraalisesti oikeita asioita. } \\
\text { Alatyypit: } \\
\text { - Seurauksellinen legitimiteetti: aikaansaan- } \\
\text { nokset tuottavat legitimiteettiä. } \\
\text { - Prosessilegitimiteetti: organisaation prosessit } \\
\text { ja työskentelytavat ovat asianmukaisia. } \\
\text { - Henkilökohtainen legitimiteetti: rakentuu } \\
\text { työntekijöiden henkilökohtaisen statuksen, } \\
\text { maineen ja karisman varaan. } \\
\text { - Rakenteellinen legitimiteetti: liittyy organi- } \\
\text { saation yleisesti hyväksyttyyn mandaattiin } \\
\text { suorittaa tehtäviään ja olla olemassa. (Such- } \\
\text { man 1995, 579-582.) }\end{array}$ & $\begin{array}{l}\text { Tuodaan esiin niiden tahojen } \\
\text { arvoja, joiden parissa legitimi- } \\
\text { teetin halutaan vahvistuvan. } \\
\text { Riskinä on, että legitimiteetti } \\
\text { heikkenee samalla toisin ajatte- } \\
\text { levien keskuudessa. }\end{array}$ \\
\hline Pragmaattinen & $\begin{array}{l}\text { Perustuu toimintaan ja sen tuloksiin sekä nii- } \\
\text { den mukanaan tuomaan vaikutusvaltaan. } \\
\text { Alatyypit: } \\
\text { - Vaihdannan legitimiteetti: sidosryhmät tuke- } \\
\text { vat organisaatiota siksi, että toiminnan tulok- } \\
\text { set auttavat heitä omassa toiminnassaan. } \\
\text { - Vaikutusvallan legitimiteetti: sidosryhmät } \\
\text { tukevat organisaatiota, koska näkevät sen } \\
\text { kytkennän laajempiin intresseihin, kuten } \\
\text { sivistykseen tai valtaan. } \\
\text { - Taipumuksellinen legitimiteetti: organisaa- } \\
\text { tion erityisyys tunnistetaan ja sitä pidetään } \\
\text { moraalisesti vastuullisena niin, että jo sen } \\
\text { tavoitteet, tyyli ja persoonallisuus tuottavat } \\
\text { legitimiteettiä. (Suchman 1995, 578-579.) }\end{array}$ & $\begin{array}{l}\text { - Mukauttamisen strategia: muo- } \\
\text { kataan organisaatiota sidosryh- } \\
\text { mien tarpeisiin paremmin sopi- } \\
\text { vaksi; tehdään aktiivista yhteis- } \\
\text { työtä sidosryhmän kanssa. } \\
\text { - Valikoinnin strategia: vakuute- } \\
\text { taan potentiaaliset sidosryhmät } \\
\text { siitä, että organisaation tuotok- } \\
\text { set vastaavat heidän tarpeitaan. } \\
\text { - Manipulointi: laajempi julkinen } \\
\text { mainonta, jonka kautta "hil- } \\
\text { jaisia" sidosryhmiä yritetään } \\
\text { saada vakuuttuneeksi siitä, että } \\
\text { myös heillä voisi olla tarve käyt- } \\
\text { tää legitimiteettiä etsivän orga- } \\
\text { nisaation tuotetta tai palvelua. }\end{array}$ \\
\hline Kognitiivinen & $\begin{array}{l}\text { Perustuu itsestäänselvyyksiin, oletuksiin ja } \\
\text { hiljaisesti hyväksyttyihin toimintatapoihin. } \\
\text { Alatyypit: } \\
\text {-Ymmärrettävyys: rakentuu yleisesti jaettujen } \\
\text { kulttuuristen käsitysten varaan } \\
\text {-Itsestäänselvyys: legitimiteetin muoto, mutta } \\
\text { samalla vaikeasti saavutettavin. (Suchman } \\
\text { 1995, 582-583.) }\end{array}$ & $\begin{array}{l}\text { Syntyy hitaasti, on seurausta } \\
\text { kertyneistä kokemuksista ja } \\
\text { muita pysyvämpi. }\end{array}$ \\
\hline
\end{tabular}


Viestinnäntutkimuksen näkökulmasta keskeistä on, että legitimiteettiä määritellään ja rakennetaan viestinnällisissä prosesseissa usein julkisuuden kautta (Van Leeuwen 2007; Joutsenvirta \& Vaara 2009; Vaara \& Tienari 2008; Porttikivi 2016). Organisaatiotoimijat pyrkivät tyypillisesti rakentamaan legitimiteettiä viestinnän kautta erilaisten diskursiivisten strategioiden avulla (Weber 1964; Vaara ym. 2006; Tost 2011), vetoamalla esimerkiksi auktoriteetteihin, moraalisiin asetelmiin, järkiperusteluihin tai narratiivisiin myytteihin (Van Leeuwen 2007). Median kaltainen institutionalisoitunut legitimiteettiarvioija joko toisintaa näitä diskursiivisia rakennelmia tai mahdollisesti haastaa niitä omissa diskursseissaan. Media näyttäytyy legitimaatiokysymyksissä eräänlaisena kollektiivisen tolkullistamisen (sensemaking) tilana (Vaara \& Tienari 2002).

Viestinnällisen, diskursiivisen legitimaation kannalta nykyisessä hybridissä mediatilassa oleellisia voivat olla myös muiden kuin vakiintuneiden mediatoimijoiden kuten journalistien äänet. Verkkoalustojen ja sosiaalisen median kautta legitimiteettiarviointeja esittävät julkisesti sellaiset toimijat - yksittäisistä kansalaisista kansalaisjärjestöihin ja työntekijöihin - joiden on ollut paljon vaikeampaa osallistua julkisiin keskusteluihin ennen sosiaalista mediaa. Heillä on oma legitimiteettinsä, joka vaikuttaa arvioihin ja niiden uskottavuuteen. Verkkojulkisuus muuttaa yhteiskunnallisen legitimiteetin arvioinnin prosessia moniäänisemmäksi ja kiistelevämmäksi (Porttikivi 2016; Ojala ym. 2019). Samalla teknologioiden tarjoamat mahdollisuudet vaikuttavat siihen, miten organisaatioita koskevia arviointeja muotoillaan ja jaetaan (Laaksonen 2017). Lisäksi hybridissä mediatilassa (Chadwick 2013) erilaiset mediamuodot ovat sulautuneita ja sekoittuneita, ja sisällöt kiertävät mediasta toiseen. Uutismedia syöttää puheenaiheita sosiaaliseen mediaan, mutta myös sosiaalisen median diskurssit ja kiistelyt päätyvät usein uutismedian agendalle. Hybridi mediatila mahdollistaa julkisen keskustelun manipuloinnin ja toimijan oman kannan legitimoinnin piilovaikuttamisen keinoin (Woolley \& Howard 2019). Monelle perinteiselle organisaatiolle, kuten myös yliopistolle, hybridi mediatila on hallitsemattomuudessaan vaikea maineenhallinnan areena.

\section{Yliopiston legitimiteetti ja markkinaistumiskehitys}

Yliopisto on vanha eurooppalainen instituutio, jonka toiminnan ydin, tutkimus ja opetus, on pysynyt suunnilleen samana koko sen tuhatvuotisen historian ajan (Kolbe 2012; Korpela \& Nevala 2020). Yliopisto-organisaation yleinen legitimiteetti lähtee siitä, että sen toiminta on yleisesti hyväksyttyä ja että se toimii tiettyjen yhteisesti jaettujen normien, arvojen ja uskomusten pohjalta. Suchmanin (1995) tunnistamana arkkityyppinä se on yhteiskunnallinen, hyväluonteinen instituutio: pysyvä, rakenteellisesti legitiimi organisaatio. Yliopiston toiminnan mahdollistavat siihen itseensä instituutiona ja sen toimintaan liitetyt itsestäänselvyydet, joita harvemmin kyseenalaistetaan (Palazzo \& Scherer 2006, 72). Yliopisto nauttii siis jossakin määrin kognitiivista legitimiteettiä. Toisaalta yliopistoa voidaan arvioida myös pragmaattisesti sen tuottaman hyödyn 
pohjalta, esimerkiksi tutkintojen laadun tai tutkimuksen yhteiskunnallisen hyödynnettävyyden kautta. Nämä arvioinnit kytkeytyvät myös moraaliseen legitimaatioon, joka on positiivinen yhteiskunnan normeihin perustuva arvio organisaatiosta ja sen toiminnasta (Suchman 1995, 579). Kuten edellä totesimme, molempia rakennetaan ja arvioidaan diskursiivisesti.

Yliopiston legitimiteetti hyötyä ja vaihtoarvoa korostavassa markkinataloudessa on ollut haasteiden alla viime vuosikymmenten julkisessa keskustelussa. Miten yliopiston legitimiteettiä voidaan ja pitää rakentaa, ja kenelle? Julkisia varoja käyttävänä instituutiona yliopiston toimintaan vaikuttavat laajasti sen sidosryhmien mielipiteet (ks. Luoma-aho 2005, 16; Ridell 2008). Nykypäivän yliopiston legitimiteetin olennainen osa on näin myös se, että yliopisto nähdään paitsi uskottavana toimijana myös haluttavana opiskelu- ja työpaikkana (ks. Deephouse \& Carter 2005, 330-331; Rauschnabel ym. 2016; vrt. Lattu 2020). Lisäksi kasvaneet vaatimukset yliopistojen tuottamasta yhteiskunnallisesta hyödystä ja niissä tuotettujen tutkintojen työelämärelevanssista ovat laajentaneet merkittävien sidosryhmien kokoonpanoa ja niiden edustamien käsitysten painoarvoa. Markkinaistuminen ja promotionaalisuus näkyvät nykyisin myös paitsi yliopistojen verkkoviestinnässä ja painotuotteissa myös laajemmin hallinnon teksteissä (Fairclough 2003, 33, 221; Chapleo ym. 2011; Solin 2006, 89; Tirronen 2014).

Yliopistojen markkinaistumisen kansainvälisessä kehyksessä suomalaiset korkeakoulut seuraavat maailmanlaajuisia trendejä (esim. Molesworth ym. 2011; Jessop 2017, 855). Toisaalta Suomen konteksti poikkeaa monien muiden maiden tilanteesta siinä, että suomalaisten korkeakoulujen rahoitus pohjautuu tulosperustaisuudestaan huolimatta edelleen pääosin valtionrahoitukseen eikä esimerkiksi lukukausimaksuihin, omaisuuden tuottoon tai yksityisten lahjoittajien varaan nojaaviin rahastoihin. Vuonna 2010 voimaan tullut yliopistolaki muutti kuitenkin perustavalla tavalla suomalaisten yliopistojen ja korkeakoulujen asemaa (OKM 2016). Ennen uudistusta korkeakoulut olivat Suomessa virallisesti valtion tilivirastoja, joiden rahoitus oli taattu valtion budjetissa ja henkilöstö oli virkasuhteessa. Uudistus erotti ne ainakin muodollisesti julkisen vallan piiristä, antoi niille hallinnollisen ja taloudellisen autonomian sekä oikeuden harjoittaa liiketoimintaa. Yliopistojen hallituksista tuli strategisia päätöksentekijöitä, ja rehtoreiden asema muuttui toimitusjohtajaa vastaavaksi. Suomalaisten korkeakoulujen tulospaineet ovat 2010-luvulla kasvaneet selvästi muun muassa tuotettujen tutkintojen, tutkimuksen vaikuttavuuden ja taloudellisen tasapainon saavuttamisen suhteen. Yliopistot ovat uuden lain aikana toteuttaneet muun muassa varainkeruukampanjoita, joiden tarkoituksena on ollut hankkia yksityistä rahoitusta tukemaan perustoimintaa - tutkimusta, opetusta ja yhteiskunnallista vaikuttavuutta.

Suomeen on 2010-luvulla syntynyt kaksi uudentyyppistä, säätiömuotoista korkeakoulua, Aalto-yliopisto (2010) ja Tampereen yliopisto (2018), joiden hallitukset ovat koostuneet lähinnä yliopistoyhteisön ulkopuolisista jäsenistä. Tämä on mahdollistanut vahvemman strategisen johtamisen. 1990-luvulta lähtien julkisjohtaminen (New Public Management) sekä koulutuksen ja tutkimuksen kaupallistaminen ovat vaiheittain ohjanneet yliopistoja kohti yritystyyppisiä toimintatapoja (ks. Patomäki 2005). Vaikka yliopistoja ajatellaan "uudella tavalla" osana yritysmaailmaa ja markkinaehtoista kor- 
keakoulukenttää, niiden asema on samaan aikaan turvattu Suomen perustuslaissa. Perustuslaissa säädetään tieteen ja taiteen vapaudesta sekä yliopistojen itsehallinnosta, joka on pyritty takaamaan erityisesti valtion rahoituksen turvin.

Yliopiston näkökulmasta omistajuuteen, rahoitukseen ja hallintotapaan liittyvät perustavanlaatuiset muutokset tarkoittavat väistämättä organisaatiomuutosta, jolla on vaikutuksia myös organisaation legitimiteettiin. Yleisesti legitimiteetin kokemus edellyttää, että sekä ulkoiset että sisäiset sidosryhmät voivat hyväksyä muutoksen ja tunnistaa sen yliopiston arvojen ja kulttuurin mukaiseksi (Pringle \& Fritz 2019, 22). Legitimiteettiteorian näkökulmasta yliopisto-organisaation toimintaa ohjaavat ja reunustavat yhteiskunnalliset normit ovat muutoksessa, jolloin sen moraalinen legitimaatio horjuu. Suchmanin (1995) mukaan etenkin moraalista legitimaatiota voidaan yrittää vahvistaa noudattamalla strategiaa, jossa kohdeorganisaatiota ja sen toimintaa muokataan vähitellen kohti toivottua organisaatiomuotoa. Tällöin legitimaatio rakentuu vähitellen, kun organisaatioon perustetaan ensin osia, jotka koetaan legitiimeiksi. Kun siirtyminen uuteen organisaatiomuotoon ei tapahdu kerralla, vältytään jyrkiltä vertailuilta aikaisempien ja uusien käytäntöjen välillä (Suchman 1995, 587-588).

Osana näitä prosesseja strategisen viestinnän, markkinoinnin ja suoranaisen brändäyksen merkitys korostuu aiempaan verrattuna (Aula ym. 2015; Ainiala ym. 2020; Dean ym. 2016). Tampereen uuden muotoisen yliopiston toimintaa, viestintää ja mainetta koskeva keskustelu havainnollistaa selkeästi, miten organisaation hankittu ja koettu kognitiivinen legitimiteetti muutostilanteessa vähitellen murentuu ja muuntuu moraalisen legitimiteetin kiistoiksi (vrt. Kuusela ym. 2019; Lattu 2020). Niitä käydään diskursiivisesti julkisuudessa, jossa yliopiston kognitiivinen legitimiteetti päätyy sosiopoliittisen arvioinnin piiriin (ks. Bitektine 2011). Näin itsestään selvänä pidetty status yliopistona ei enää riitä legitimiteetin saavuttamiseen, vaan julkisessa keskustelussa nostetaan esiin vihjeitä siitä, missä määrin organisaatiolla kenenkin näkökulmasta on olemassaolon oikeus ja kenelle siitä on hyötyä. Tämän artikkelin teoreettisena kontribuutiona on tarkastella sitä, miten legitimiteettikamppailu julkisuudessa etenee ja mikä rooli eri toimijoilla, kuten yksittäisillä henkilöillä tai mediatoimijoilla, tässä kokonaisuudessa on.

\section{Aineisto ja menetelmät}

Pääasiallinen aineistomme koostuu 9303 sosiaalisen median julkaisusta, joissa esiintyy merkkijonot tampereuni, tuninaama tai tunipalo. Aineisto on kerätty aikaväliltä 1.1.-24.3.2020 ja se on ladattu käyttämällä suomalaista julkista sosiaalisen median keskustelua kattavasti tallentavaa Mohawk-yrityksen tietokantaa (ks. Pöyry ym. 2018). Julkaisuista valtaosa on twiittejä ( $n=9$ 215). Vaikka suurin osa esiintymistä on aihetunnisteita - esimerkiksi \#tampereuni on Tampereen yliopiston virallinen hashtag ja käyttäjänimi - mukana on myös tavallisia sanaosumia ja käyttäjätilejä. Emme rajanneet aineistoa suoraan aihetunnisteilla, koska ne ovat vain pieni osa verkkokeskustelua ja ne indikoivat keskustelijoiden halua osallistua juuri aihetunnisteen ympärillä 
käytävään keskusteluun (ks. McKelvey ym. 2014; Koskela \& Sihvonen 2018). Hashtageista suosituin on aineistossa ollut \#tuninaama (1 238 osumaa), jonka suosio näyttää jatkuvan myös tarkastellusta jaksosta eteenpäin. Sen käyttötapa vaikuttaa kuitenkin muuttuneen maaliskuun jälkeen enemmän yhteisölliseksi ja ironiseksi, mikä vaikutti aineistomme rajaukseen. Koronakriisin myötä sosiaalisen median keskustelu vaimeni maaliskuun puolivälin jälkeen (ks. kuvio 1).

Toinen tutkimuksessa käytetty aineisto koostuu verkkouutisista, joissa on mainittu sanat "tampere" ja "yliopisto" joko leipätekstissä tai otsikossa ja jotka on julkaistu aikavälillä 1.1.2019-24.3.2020. Journalistisen aineiston otos laajennettiin vuodelle 2019, jotta sosiaalisen median keskusteluissa esiin tulevia teemoja olisi mahdollista taustoittaa. Tampereen uuden yliopiston synty on pitkä prosessi (Poutanen ym. 2020), mutta sosiaalisessa mediassa keskustelu kävi Mohawkin tietokantaan tehtyjen hakujen perusteella kiivaimmillaan juuri kevättalvella 2020. Rajasimme tarkastelluiksi medioiksi Aamulehden, Helsingin Sanomat ja Ylen. Näin ollen aineisto kattaa kaksi suurinta valtakunnallista mediaa sekä Tampereen alueen keskeisen paikallislehden. Myös tämä aineisto ladattiin Mohawkin tietokannasta. Se sisältää yhteensä 245 osumaa. Aineisto käytiin läpi taulukkomuodossa otsikoiden perusteella ja sieltä valittiin laadulliseen analyysiin selvästi yliopiston organisaatiomuutokseen liittyvät tekstit, joita oli yhteensä 29.

Journalistista media-aineistoa täydennettiin lisäksi keräämällä erikseen manuaalisesti Tampereen yliopiston organisaatiouudistuksesta erityisen aktiivisesti kirjoittaneesta Suomen Kuvalehdestä sen arkiston kautta kymmenen aiheeseen liittyvää artikkelia. Artikkelit kerättiin edeten professori Pertti Alasuutarin mielipidekirjoituksesta (7.6.2018) lehden oman linkityksen mukaisesti aina seuraaviin linkitettyihin artikkeleihin, joista tuoreimmat tähän tutkimukseen mukaan ehtineet artikkelit on julkaistu 20.2.2020. Koko aineisto on kuvattu taulukossa 2.

Taulukko 2. Tutkimuksessa käytetty aineisto ja sen kuvaus.

\begin{tabular}{|l|l|l|}
\hline Aineisto & $\mathbf{n}$ & Kuvaus \\
\hline $\begin{array}{l}\text { Sosiaalisen median viestit } \\
\text { (Kaikki viestit ovat julkisia ja } \\
\text { lähetetty välillä 1.1.-24.3.2020) }\end{array}$ & 9303 & $\begin{array}{l}\text { Twitter (retwiitit mukaan lukien) } 9215 \\
\text { Facebook 70 } \\
\text { Instagram 12 } \\
\text { Keskustelupalsta 5 } \\
\text { Blogit 1 }\end{array}$ \\
\hline $\begin{array}{l}\text { Journalistinen aineisto (Tampereen } \\
\text { yliopiston organisaatiouudistusta } \\
\text { koskevat tekstit 7.6.2018-24.3.2020) }\end{array}$ & 39 & $\begin{array}{l}\text { Aamulehti 12 } \\
\text { Yle 8 } \\
\text { Helsingin Sanomat 9 } \\
\text { Suomen Kuvalehti 10 }\end{array}$ \\
\hline
\end{tabular}


Aineistoja analysoitiin rinnakkain. Sosiaalisen median koko aineistosta rajattiin ensin pois uudelleentwiittaukset, minkä jälkeen kaikki loput viestit ( $n=4$ 124) käytiin ensin läpi kursorisesti ja taulukkomuotoiseen dataan merkittiin erillisen sarakkeen avulla jokainen yliopiston organisaatiouudistukseen liittyvä viesti $(n=1369$, ks. kuvio 1). Kriteerinä oli, että viesti käsittelee yliopiston legitimiteettiä: yliopistoa organisaationa, organisaatiouudistusta tai siihen liittyvää julkisuutta joko positiivisena, neutraalina tai negatiivisena ilmiönä. Näin ollen ulkopuolelle rajautuivat esimerkiksi Tampereen yliopistolla tehtävää tutkimusta tai tutkimukseen liittyviä tapahtumia käsittelevät viestit sekä yhteishakuun liittyvä keskustelu, vaikka näilläkin luonnollisesti on ollut oma merkityksensä yliopiston legitimiteetin julkisessa rakentumisessa. Kaikki aineistot luettiin kronologisesti järjestyksessä. Keskusteluaiheiden eteneminen eri medioissa aikajärjestyksessä kirjattiin yhteiseen taulukkoon, jossa kuvattiin aineistojen pääsisällöt kolmesta eri näkökulmasta: journalistisen median, sosiaalisen median ja Tampereen yliopiston toiminnan näkökulmista. Sosiaalisen median aineistoa läpikäytäessä seurattiin lisäksi linkityksiä keskusteluissa keskeisiksi nousseisiin muihin lähteisiin, kuten blogikirjoituksiin ja kolumneihin.

Kuvio 1. Tampereen yliopiston legitimiteettiin ja organisaatiouudistukseen liittyvien alkuperäisten sosiaalisen median päivittäiset viestimäärät ( $n=1364)$.

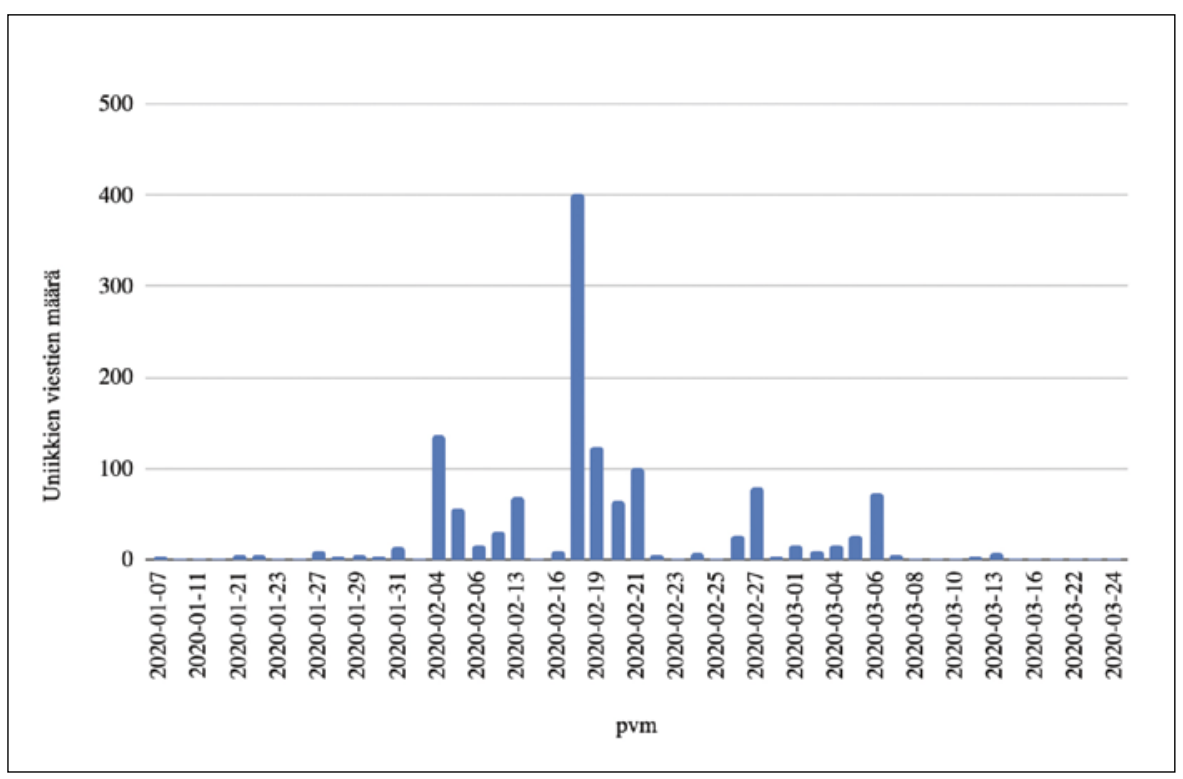

Seuraavassa analyysiluvussa keskusteluaiheiden etenemistä kuvaavaa taulukkoa sekä molempia aineistoja luetaan rinnakkain ja niiden sisältöjä tulkitaan legitimiteettiteorian näkökulmasta tarkastelemalla sitä, mitä eri legitimiteetin tyyppejä ja niiden alalajeja (Suchman 2005) keskusteluissa on tunnistettavissa. Analyysi etenee kronolo- 
gisesti, koska tarkastelussa on nimenomaan keskustelu ja sen edetessä rakentuva legitimiteettikamppailu uuden muotoisen yliopiston puolesta ja sitä vastaan. Artikkelin päätösluvussa analyysissa saadut tulokset vedetään yhteen ja hybridin mediatilan eri keskusteluympäristöjä verrataan toisiinsa legitimiteettikamppailujen näkökulmasta.

Esitämme analyysimme tueksi poimintoja molemmista aineistoista. Sosiaalisen median osalta viestien lähettäjät ja niissä esiintyvät käyttäjänimet on valtaosin poistettu tutkimuseettisistä syistä. Vaikka twiitit ovat lähtökohtaisesti julkisia, emme koe että henkilöiden esiin nostaminen on tutkimusongelmamme kannalta oleellista, paitsi jos kyseessä on selkeästi omalla nimellään julkisuudessa toimiva henkilö (esim. toimittaja, poliitikko) tai Tampereen yliopiston nimekäs toimija (esim. rehtori, professori). Tiedostamme, että alkuperäisten viestien löytäminen verkosta voi tästä huolimatta olla mahdollista pelkän tekstisisällön perusteella (ks. Kosonen ym. 2018). Haluamme kuitenkin minimoida tutkimusaineistossamme esiintyville henkilöille aiheutuvaa mahdollista haittaa siten, että estämme käyttäjänimien ja henkilönimien suoran kytköksen tähän artikkeliin ja sen kehystykseen esimerkiksi hakukoneissa. Aineistosta poimitut kuvaesimerkit on julkaistu käyttäjän antamalla luvalla.

\section{Tampereen yliopisto legitimaatiokiistojen polttopisteessä}

\section{Delegitimaation korostuminen journalismissa}

Journalistisen aineiston perusteella uuden Tampereen yliopiston legitimiteetistä käyty keskustelu on keskittynyt vahvasti moraaliseen legitimaatioon. Tämä on luontevaa siinä mielessä, että keskustelussa nimenomaan törmäsivät yhtäältä perinteisen yliopiston ja tutkimuksen vapauden arvot ja toisaalta brändi- ja markkinointiviestinnän myyntipuheeseen kietoutuvat arvot. Kuvaamme seuraavassa ensin moraalisen legitimiteetin ilmenemismuotoja aineistossa, jonka jälkeen tarkastelemme pragmaattisen legitimiteetin ilmenemistä sidosryhmien odotuksien näkökulmasta sekä pohdimme lopuksi lyhyesti kognitiivista legitimiteettiä.

Uuden Tampereen yliopiston legitimiteettikamppailua on käyty journalismissa erityisesti kesästä 2018 kesään 2020. Samaan aikaan kun yliopiston julkisuuskuvaa ja toimintaa on pyritty legitimoimaan vahvalla brändiviestinnällä, esiin on noussut runsaasti delegitimoivia näkökulmia. Tampereen uuden muotoinen yliopisto aloitti virallisesti vuoden 2019 alussa, mutta jo edellisenä vuonna sen viestintää ja toimintakulttuuria käsiteltiin journalismissa poikkeuksellisen runsaasti. Tampereen yliopiston tutkija Jussi Jalonen (2018) tiivistää blogissaan, miten muun muassa Helsingin Sanomissa, Kauppalehdessä ja Talouselämässä uudesta yliopistosta kirjoitettiin uudenlaisen yliopistokulttuurin airueena. Siihen näytti kuuluvan entistä syvempi tietoisuus tutkimustoiminnan julkisesta rahoituksesta ja vastuu verorahojen käytöstä, yliopistojen perusrahoituksen vähenemisen hyväksyminen sekä yliopistoväen muutosvastarinta, joka näyttäytyi uudenlaisen menestyksen esteenä (esim. Talouselämä 16.8.2018). Myös yksittäiset professorit aiheuttivat ulostuloillaan (Alasuutari 2018; Hämeen-Ant- 
tila 2018) julkista keskustelua muun muassa yliopiston tutkimusstrategiaan ja missioon liittyvistä kitkeristä valtataisteluista (ks. Niemelä 2018).

Kriittiseen tieteelliseen perinteeseen on kuulunut, että yliopisto-organisaation jäsenet saavat julkisesti arvioida työnantajaansa ja työyhteisöään, eikä työntekijän lojaliteettivelvoitetta ole juuri tarkkailtu. Professorien julkisen kritiikin lisäksi myös muut henkilöstöryhmät ovat saaneet arvostella työnantajansa toimintaa julkisuudessa näkyvin ja kuuluvin tavoin. Esimerkiksi Tampereen yliopiston filosofian yliopistonlehtori Jani Hakkaraisen 19.2.2020 alulle panemaa ja lopulta 539 nimeä kerännyttä julkista vetoomusta yliopiston viestinnän uudelleenorganisoinnista käsiteltiin näyttävästi Suomen Kuvalehden jutussa (Keski-Heikkilä 2020a). Yliopiston viestintään keskittyvä artikkeli toi esiin, miten vetoomuksen ytimessä olivat vaatimukset yliopiston verkkosivujen selkiyttämistä, brändin ja logon kriittisen käsittelyn sallimista sekä "pöhinäretoriikasta" luopumista. Viikkoa myöhemmin, 26. helmikuuta, vetoomuksen esille nostamista asioista samassa lehdessä haastateltu Tampereen yliopiston hallituksen puheenjohtaja Ilkka Herlin myönsi selväsanaisesti, että viestinnän lähtökohdat on otettu yritysmaailmasta eivätkä ne sovi sellaisenaan yliopistoympäristöön (KeskiHeikkilä 202ob).

Yliopistojen voidaan ajatella lähtökohtaisesti näyttäytyvän rakenteellisesti legitiimeinä toimijoina, joiden koetaan suorittavan yhteiskunnallisesti hyväksyttyä tehtävää (Suchman 1995). Valtakunnalliseen julkisuuteen nousseet tapaukset, joissa professorit ja muut henkilöstön jäsenet kritisoivat voimakkaasti Tampereen yliopiston viestinnässä korostuvia arvoja ja puhutteluja, kertovat yliopiston moraaliseen legitimiteettiin liittyvistä kamppailuista. Moraalisen legitimiteetin näkökulmasta legitimiteettikamppailun ytimessä on se, että säätiöyliopisto on pyrkinyt rakentamaan legitimiteettiään vetoamalla niiden tahojen arvoihin, joiden parissa legitimiteettiä on haluttu vahvistaa. Tällaisena tahona näyttäytyy liike-elämä, erityisesti teknologiateollisuus, mutta myös opetus- ja kulttuuriministeriö, jonka toiveisiin on haluttu vastata. Tällä tavalla on tuettu näiden tahojen odotusten mukaista rakenteellista legitimiteettiä, eli yleisesti hyväksytyn mandaatin ylläpitämistä, kuten seuraavasta esimerkistä nähdään:

Tampereen korkeakoulujen yhdistäminen alkoi vuonna 2013. Tampereen yliopiston silloinen rehtori Kaija Holli teki aloitteen, sitten tehtiin selvitys. Opetusministeriössä iloittiin, että hajanainen korkeakoulukenttä tiivistyisi entisestään. Suomalaisia yliopistoja on uudistettu yritysmaailman opein siitä saakka, kun Jyrki Kataisen (kok) "fantastiseksi" kuvaama yliopistouudistus tuli voimaan vuonna 2010. Silloin yliopistot irrotettiin valtionhallinnosta ja niiden autonomiaa lisättiin. Vuonna 2015 Tampereen yliopisto, Tampereen teknillinen yliopisto (TTY) ja Tampereen ammattikorkeakoulu tekivät myönteisen päätöksen yhdistymisestä. Projektin nimeksi tuli Tampere3. (Onninen 2019.)

Samaan aikaan on kuitenkin toteutunut riski, että legitimiteetti on heikentynyt toisaalla - henkilöstön, etenkin tutkijoiden ja opiskelijoiden, sekä koko akateemisen yhteisön joukossa. Prosessilegitimiteetin eli prosessien asianmukaisuuden näkökulmasta uuden organisaation työskentelytapoja on kyseenalaistettu nostamalla esiin 
hallituksen mielivaltaan, rekrytointeihin ja rehtorivalinnan salailuun liittyviä ongelmia. Esimerkiksi Suomen Kuvalehti (Onninen 2019) raportoi Elinkeinoelämän valtuuskunnan johtajan ja Aamulehden päätoimittajan Matti Apusen valinnasta työelämäprofessoriksi ilman asiantuntijalausuntoja ja Helsingin Sanomat (Harju 2020) kertoi yliopiston henkilöstöpäällikön neuvoneen ei-valittuja rehtorihakijoita vetämään paperinsa pois, jotta heidän tietonsa pysyisivät salassa. Tällaiset median esiin tuomat toistuvat prosessilegitimiteettiä haastavat väitteet nakertavat vähitellen moraalista legitimiteettiä.

Journalistisessa mediassa pääsevät ääneen myös henkilöt, joilla on henkilökohtaista legitimiteettiä eli varsinkin statusta ja mainetta asemansa ansiosta. Esimerkiksi professori Pertti Alasuutari kirjoitti Tampereen yliopistoa vahvasti delegitimoivan mielipidekirjoituksen Suomen Kuvalehteen 7. elokuuta 2018. Kirjoituksessaan hän kritisoi erityisesti yliopiston muuttunutta luonnetta ja organisaatiota, jota hän ei enää kokenut omakseen:

Olen tehnyt koko akateemisen urani Tampereen yliopistossa, iloinnut sen menestyksestä ja tehnyt sen eteen paljon töitä tutkimustyölläni ja hankkimallani tutkimusrahoituksella. Nyt, kun Tampereen korkeakoulut yhdistyvät uudeksi säätiöyliopistoksi, en ole enää varma, haluanko jatkaa uraani täällä. [...] Nyt minusta näyttää, että Tampereen yliopistosta ollaan tekemässä jonkinlaista kehittämiskeskusta tai tutkimus- ja kehitysyksikköä, ei suinkaan monialaista tiedeyliopistoa. (Alasuutari 2018.)

Alasuutarin ulostulo on esimerkki siitä, miten henkilökohtainen legitimiteetti voi toimia vahvana delegitimoivana tekijänä. Toisaalta henkilökohtaisella legitimiteetillä on käyty myös haastamaan näitä väitteitä ja puolestaan tuettu uuden muotoisen yliopiston moraalista legitimiteettiä. Entisen Tampereen teknillisen yliopiston professorit julkaisivat Alasuutarin kirjoitukseen "vertaisarvioivan" vastineen, jossa he korostivat yliopiston strategisen johtamisen hyviä puolia ja henkilöstön ja opiskelijoiden tyytyväisyyttä (Valkama ym. 2018). Lisäksi henkilökohtaisen legitimiteetin kautta on myös myönnetty, että yritysmaailman viestintämallit eivät ole suoraan siirrettävissä yliopistoon (hallituksen puheenjohtaja Herlin Suomen Kuvalehdessä, ks. Keski-Heikkilä 202ob).

Hybridissä mediatilassa journalismi toistaa delegitimoivaa viestiä vahvemmin kuin legitimoivaa, koska negatiivinen uutinen on "parempi" uutinen kuin positiivinen (vrt. Galtung \& Ruge 1965). Aiemmassa tutkimuksessa onkin todettu, että mediaa ei lähtökohtaisesti kiinnosta stabiilissa tilassa oleva instituutio (Bitektine \& Haack 2015, 56). Tarkastellussa aineistossa tämä näkyy esimerkiksi siinä, että myös jokaisessa Tampereen yliopiston legitimaatiota pönkittävässä jutussa media toistaa tapahtumien ja puheenvuorojen delegitimoivat aspektit. Näin tapahtuu erityisesti niissä teksteissä, joissa tapahtumien kulkua analysoidaan ja arvioidaan.

Yliopiston pragmaattinen legitimiteetti perustuu siihen, että sen tutkimus ja koulutus ovat tarpeellisia ja kysyttyjä ja että niiden kautta syntyy tiettyä vaikutusvaltaa. Eri sidosryhmät voivat tukea yliopiston pragmaattista legitimiteettiä eri syistä. Niin sanotussa vaihdannan legitimiteetissä sidosryhmä kokee, että yliopiston toiminta auttaa heitä omassa toiminnassaan. Vaihdannan legitimiteetti on osa pragmaattista legitimiteettiä 
ja tärkeä yliopiston toimintaa legitimoiva näkökulma. Esimerkiksi Helsingin Sanomat (Grönholm 2019) siteeraa TTY:n opiskelijaa, joka näkee yliopiston uudistuksen lähinnä laajentuneena kurssitarjontana ja tuottaa näin osaltaan uuden muotoiselle yliopistolle pragmaattista legitimiteettiä.

Perinteisen yliopiston arvojen kannattajien silmissä yliopiston brändiviestintä ja johtamiseen liittyvä julkinen keskustelu ovat haastaneet pragmaattisen legitimaation osalta myös siihen sisältyvää yliopistoinstituution vaikutusvallan legitimiteettiä. Siinä tieteen ja korkeimman opetuksen legitimaation nähdään perustuvan laajempiin intresseihin. Sidosryhmät tukevat yliopistoa, koska sillä on yhteys moniin hyviin yhteiskunnallisiin päämääriin kuten kansalaisten koulutukseen ja sivistyksen tasoon. Pitkittyessään delegitimoiva julkinen keskustelu voi haastaa jopa yliopistoinstituutiossa vahvan taipumuksellisen legitimiteetin, jonka mukaan yliopiston erityisyys riittää takaamaan vastuullisen toimijan maineen. Näin ajatellen jo yliopiston tavoitteet ja viestinnän tyyli tuottavat legitimiteettiä (vrt. Suchman 1995, 578-579). Uudistumisen ongelmaksi muodostuu se, että kun tavoitteet ja myös tyyli rakennetaan tietoisesti viestinnällä palvelemaan muunlaista toimijaa kuin yliopisto perinteisesti on ja Tampereen yliopiston sidosryhmät sen kokevat olevan, taipumuksellinen legitimiteetti rikkoutuu ja se täytyy rakentaa uudelleen uuden tyylin mukaisesti.

Kognitiivisen legitimiteetin saavuttaneen organisaation legitimiteetti on itsestään selvä ja pysyvä. Nykyisen jatkuvan muutoksen ja hybridin mediatilan näkökulmasta pysyvyys on kuitenkin vaarallinen perusoletus. Yliopiston kognitiivisen legitimiteetin itsestään selvänä pitäminen muutostilanteessa saattaakin selittää, miksi muutos nousi niin voimakkaasti julkiseen keskusteluun ja tilanne kriisiytyi.

\section{Pöhinäretoriikan kriitikot sosiaalisessa mediassa}

Sosiaalisen median aineistoa kuvaavat verkkokeskustelulle tyypilliset hetkellisesti roihahtavat keskustelut (vrt. Ojala 2019; ks. kuvio 2). Ensimmäiset keskustelupiikit ovat muiden mediatekstien nostattamia, ja ne ajoittuvat tammi-helmikuulle. Keskusteluaiheissa korostuu erityisesti yliopiston viestinnän kielenkäyttö, jota verkkokommentaattorit kutsuvat "pöhinäretoriikaksi". 22. tammikuuta Tampereen korkeakouluyhteisö julkaisi Kauppalehdessä sisältöyhteistyöjutun, jossa kerrottiin innovaatioiden uuden aikakauden alkaneen ja ylistäen kuvattiin Tampereen yliopiston uudenlaista innovaatiotoimintaa:

[T]arvitsemme kuitenkin Future Findersin kaltaisia, eri alojen rajapinnoilla itsensä likoon laittavia ihmisiä, jotka ikään kuin sytyttävät pieniä innostuksen tulipaloja, [innovaatiojohtaja] Taru Pilvi kuvaa. [...] Taru Pilven mukaan kulttuurin muutos on onnistunut, jos tulevaisuudessa Tampereen yliopiston kasvatit sanan innovaatio kuullessaan ajattelevat ensiksi energistä tekemistä ja yllättäviä, absurdejakin kokoonpanoja ja vasta sen jälkeen yliopistossa syntyneitä sosiaalisia, lääketieteen ja teknologian keksintöjä. (Tampereen korkeakouluyhteisö 2020) 
Julkaisupäivänä artikkeli sai aikaan vain muutaman twiitin, mutta nousi uudelleen esille viisi päivää myöhemmin, kun Ylen toimittaja Tuija Siltamäki ihmetteli artikkelin kielenkäyttöä. Ketjun aloitusviestissä viitattiin rehtorin viestiin, jossa etsittiin osallistujia "wau-kokemuksen luomiseen" liittyvään työpajaan (ks. Onninen 2019), ja kaikkineen ketju keräsi 59 vastausta, 109 uudelleentwiittausta ja 670 tykkäystä:

Jotenkin upeaa on se, että Tampereen wau-opisto kuulostaa päivä päivältä enemmän parodialta itsestään. Tässä on esimerkiksi innovoitu teksti, jonka yksikään lause ei tarkoita mitään. (twiitti 27.1.2020)

Tässä keskustelussa pöhinäjargonille rakentuva viesti koettiin epäaidoksi, eikä yliopiston kaltaisen toimijan koettu soveliaaksi maksaa sisältöyhteistyöstä. Moraalisen legitimiteetin osalta haastetuksi tuli prosessilegitimiteetti, koska viestintää ei koettu asianmukaiseksi eikä se vastannut yhteisön arvoja. Twitter-kriitikoissa oli mukana paljon Tampereen yliopiston työntekijöitä, erityisesti inmistieteilijöitä, jotka Pertti Alasuutarin tavoin kokivat ristiriitaa yliopiston maineen ja viestinnän välillä ja tuottivat henkilökohtaisen legitimiteettinsä kautta delegitimoivaa julkisuutta uudelle yliopistolle. Normaalitilanteessa työntekijöiden henkilökohtainen status ja maine rakentavat myös organisaatiotoimijan legitimiteettiä (Suchman 1995), mutta tässä yhteydessä työntekijät kääntyvätkin delegitimoijiksi:

Hei @TampereUni, mulla olis villi ehdotus. Mitä jos monikanavaisen tarinankerronnan sijaan panostettaisiin siihen yliopiston ydintoimintaan, eli tutkimukseen ja opetukseen? \#IhminenRatkaisee \#WAU (twiitti 3.2.2020)

@käyttäjä @käyttäjä @käyttäjät @TampereUni Juuri näin. Itse olen kokenut pöhinäpuheen ja yliopistolle (mielestäni) vieraan retoriikan epäkunnioittavana meitä tutkijoita ja tieteentekijöitä kohtaan. Uuden yliopiston ulkoinen viestintä tuntuu haluavan tehdä meistä sellaisia mitä monikaan meistä ei ole. Se vieraannuttaa. (twiitti 5.2.2020)

Kritiikki hiljeni hetkeksi, mutta nousi uudelleen esille 4. helmikuuta, kun Tampereen yliopisto julkaisi viestintäasiantuntijan rekrytointi-ilmoituksen, jonka tekstissä esiintyivät tutut tulipalot supersankarivoimilla ja tarinankerronnalla ryyditettyinä. Jälleen viestintä vastasi liiketoiminnan arvoja, mutta ei yliopiston arvoja, mikä johti seurauksellisen ja prosessilegitimiteetin kannalta ongelmalliseen tilanteeseen. Tyylilajiin tarttui lukuisten muiden lisäksi Tampereen yliopiston journalistiikan professori Janne Seppänen:

Olen viestinnän proffa. Silti en ymmärrä puoliakaan tästä @TampereUni ilmoituksesta, jossa haetaan viestinnän asiantuntijaa. Joko minä tai uuden yliopistoni markkinointiviestintä on totaalisesti pihalla yliopiston ja yhteiskunnan todellisuudesta. Ei näin! [linkki] (twiitti 4.2.2020) 
Alkuvuoden kriittisen keskustelun fokuksessa on juuri ongelmallinen kielenkäyttö: verkossa kommentoivan yliopistoyhteisön näkökulmasta Tampereen yliopiston käyttämä kieli istuu huonosti yliopisto-organisaatiolle ja on pikemminkin falskia brändäämistä ja suuryritysten tyyliä. Tämän voi tulkita viestinnän tekijöiden kannalta prosessilegitimiteettiin liittyväksi ongelmaksi, koska suuri osa sidosryhmistä ei kokenut toimintatapoja asianmukaisiksi:

Juuri tulleen tiedon mukaan @TampereUni TODELLA tarvitsee sitä viestintäasiantuntijaa sammuttelemaan niitä innostuksen tulipaloja, joilla yliopiston johto yrittää aktiivisesti tuhota koko yliopiston maineen. Ei näin. \#tampere (twiitti 18.2.2020)

Haastetuksi tuli myös taipumuksellinen legitimiteetti, kun yliopistolle tyypillisenä pidetty arvokkuus tietoisesti korvattiin lähes päinvastaisella tyylillä. Tähän aiheeseen journalistisessa mediassa puuttuivat sekä Alasuutari että Herlin.

Kielenkäyttöä koskevassa keskustelussa onkin näkyvissä merkkejä paitsi jonkin verran neuvoteltavissa olevan taipumuksellisen legitimiteetin haastamisesta, jopa pysyvän, kognitiivisen legitimiteetin vähittäisestä murenemisesta. Yliopiston viestintäyksikön tuottamat julkaisut eivät vastaa sitä sävyä, mitä yliopistossa pidetään suotavana (ks. Suchman 1995, 583-583). Keskustelijat kokivat, ettei organisaation johto ymmärrä yliopistossa tehtävän työn laatua ja merkitystä ja yliopiston viestintä palkataan valehtelemaan ja kaunistelemaan organisaatiomuutoksen ongelmallisuutta. Tätä kautta keskustelu eteni nopeasti arvopuheeseen ja delegitimoiviin väitteisiin uuden yliopiston prosessien ongelmallisuudesta, kuten henkilöstön edustuksen puuttumiseen yliopiston hallituksesta, salattuun rehtorivalintaan ja organisaation päätöksentekoon. Nämä teemat liittyvät moraaliseen legitimiteettiin ja erityisesti jälleen prosessilegitimiteettiin (Suchman 1995, 579-582):

@käyttäjä @käyttäjä Koska @TampereUni pyrkii kaikin voimin unohtamaan olevansa yliopisto ja larppaa pöhinäänsä tikahtuvaa start-up-firmaa jonka koko olemassaolo kiertyy ulkopuolisten rahoittajien liehakoinnin ympärille. (twiitti 12.2.2020)

@käyttäjä @TampereUni Muutospuhe on keino peittää ongelmia, heikkoa johtamista ja muutoksen ymmärtämättömyyttä. Kysehän ei ole uudesta yliopistosta eikä korkeakouluyhteisöstä vaan yhdistyneistä organisaatiosta, joilla on historia. Sen pohjalta pitäisi rakentaa eikä kuvitellun tyhjän alun pohjalta. (twiitti 22.2.2020)

Moraaliseen, prosesseihin liittyvään legitimiteettikeskusteluun kytkeytyy myös yliopistoyhteisön häpeä ja kokemus siitä, että moraalisesti arveluttavalta näyttävä yliopistotoimija ei enää tuota sellaista pragmaattista taustatukea, jota akateeminen työntekijä toivoisi omalta yliopistolta saavansa. Kognitiivisen legitimiteetin näkökulmasta yliopisto-organisaatio työnantajana on menettänyt asemansa itsestäänselvyytenä: 
@käyttäjä @käyttäjä @käyttäjä @TampereUni Jos tämä olisi yksittäinen tapaus, tuo voisi ehkä toimia. Nyt uusi yliopisto on kuitenkin toistuvasti ja johdonmukaisesti näyttäytynyt julkisuudessa surkuhupaisana, konsulttihötön läpikyllästämänä laitoksena. Kuka sellaiseen haluaa sitoutua, laittaa rahaa tai osan elämästään? (twiitti 4.2.2020)

Ja terveisiä @TampereUni viestintään: lopettakaa se brändisekoilu ennen kuin se vie tutkinnoiltamme kaiken lopunkin uskottavuuden. (twiitti 18.2.2020)

Olen aina ollut ylpeä yliopistostani. Opetus on laadukasta, varsinkin omalla tieteenalallani. Tohtoriopiskelijana koen olevani siellä missä pitää. Silti vähän hävettää. @TampereUni toivoisin, että voisin jatkossakin olla susta ylpeä. (twiitti 21.2.2020)

Pöhinäretoriikasta syntyy kiinnostavalla tavalla myös työväline kriittiselle yleisölle sekä keino delegitimoida Tampereen yliopiston uutta brändiviestintää ja organisaatiota parodian kautta. Erityisesti Kauppalehden jutussa käytetty tulipalometafora ja siitä väännöksenä syntynyt tunipalo jää elämään verkkokeskusteluissa (ks. myös Piata 2016). Tuli- tai tunipalojen sytyttämisestä rajapinnoille muodostuu metafora, jolla Twitter-keskusteluissa viitataan alkuperäisen innovaatiotoiminnan asemesta Tampereen yliopiston viestinnällisiin epäonnistumisiin (ks. kuva 1).

Kuva 1. Tuninaama- ja tunipalo-tunnisteen yhdistävä kriittinen twiitti (Yrjönen 2020).

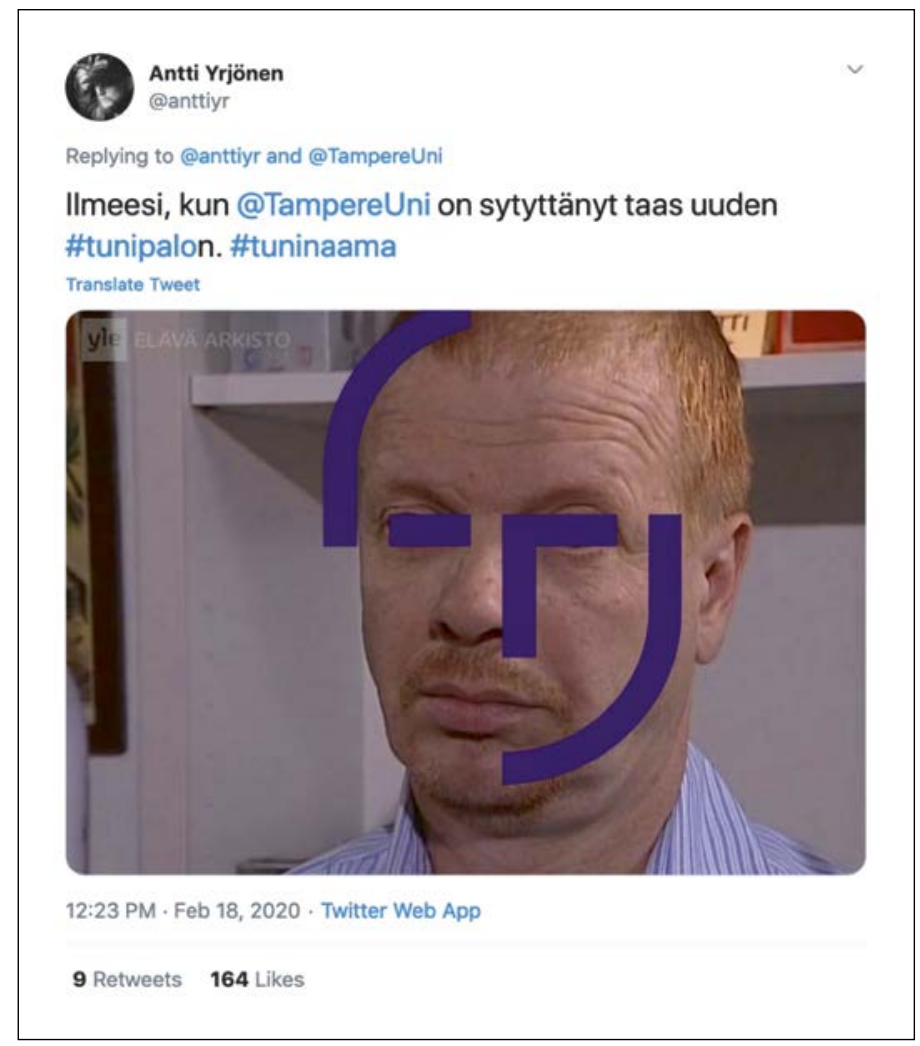




\section{Tuninaama kiistakapulana}

Ristiriita yliopiston uutta luovan brändinrakennuksen ja perinteisyyttä ja pysyvyyttä korostavan pragmaattisen ja kognitiivisen legitimiteetin välillä kulminoitui helmikuun lopulla tavoissa, joilla yliopiston logoksi lanseerattua tuninaamaa käsiteltiin ensinnäkin yliopiston viestinnässä ja toiseksi henkilökunnan ja opiskelijoiden kriittisissä ulostuloissa. Keväällä 2018 lanseerattu tuninaama ja yliopiston brändiväriksi valittu tumma violetti olivat näkyvästi esillä esimerkiksi lukuvuoden 2019 avajaisjuhlissa. Samoihin aikoihin yliopiston brändiin keskittyneessä Suomen Kuvalehden jutussa haastateltu rehtori Mari Walls kertoi olevansa erittäin tyytyväinen konsulttien luomaan sloganiin "ihminen ratkaisee" ja yliopiston siihenastiseen brändityöskentelyyn (Onninen 2019). Kuitenkin myös logoon ja sloganeihin liittyvät ristiriitaisuudet nousevat jutussa poikkeuksellisella tavalla esiin:

Viestintäohjeissa on teroitettu, että yliopistosta tulee puhua "me-muodossa", koska siitä syntyy "aidon kohtaamisen vaikutelma". Korkeakouluyhteisön lyhenne TUNI on tarkoitettu "järjestelmäkäyttöön", ei "puhuttavaksi tai kirjoitettavaksi". [--] Kun eräs tutkija oli laittanut esitysdioihin rautanaamiologolle pipon, viestintäosastolta oli tullut ukaasi: logoja ei saa muuttaa eikä sloganeille vitsailla. (Onninen 2019.)

Vuoden 2020 alussa tuninaama-logoa koskeva kiista saa aineistossamme uusia ulottuvuuksia. Opiskelijajärjestö Tampereen yliopiston vihreä vasemmisto (Viva) julkaisi 18.2.2020 verkkosivuillaan avoimen kirjeen (Taubert 2020a) vastauksena yliopiston johdon lähettämälle viestille, jossa otettiin jyrkästi kantaa Vivan 14.6.2018 eli lähes kaksi vuotta aiemmin julkaisemaan satiiriseen blogitekstiin (Taubert 2018) ja uhattiin järjestöä oikeustoimilla. Tekstissä irvaillaan perustuslain noudattamatta jättämisen olevan pinnalla oleva pöhisevä megatrendi ja vaaditaan yliopiston johtoon suurta muinaista Cthulhua, jonka "kyky tehdä vaikeita, ketteriä ja rohkeita ratkaisuja on todettu useaan kertaan maailmanhistorian aikana." Tekstin kuvituksena oli yliopiston logosta tehty muunnelma, jossa pelkistettyihin ja ilmeettömiin ihmiskasvoihin oli lisätty lonkeroita. Ensimmäinen julkisesti jaettu, Tampereen yliopiston toimintaa ironisesti kommentoiva tuninaama syntyi tuolloin, kesäkuussa 2018, mutta keskustelu sen symboliarvosta saavutti kansallisen tason julkisuuden vasta alkuvuonna 2020.

Reaktiona järjestön saamaan uhkauskirjeeseen lukuisat yliopistolaiset ja muut Twitter-käyttäjät alkoivat tehtailla omia versioitaan tuninaamasta (esim. kuva 1). Logomuunteluista raportoi myös Helsingin Sanomat 18. helmikuuta (Körkkö 2020). Logoon liittyvä ilakointi keskittyy päiviin 17.-18. helmikuuta, mutta jatkuu satunnaisesti sen jälkeenkin:

@TampereUni hallinto uhkailee yliopiston opiskelijajärjestöä tämän logomukaelman julkaisemisesta oikeustoimilla. Ilmeisesti opiskelijahuumorin perinteiden tuntemus on palanut poroksi jossakin pienessä tulipalossa, kun asiaa tästä kulmasta lähestytään. (twiitti 18.2.2020) 
@TampereUni Sytytelläänkö tässä pieniä tulipaloja sananvapauden ja immateriaalioikeuden rajapinnalla? (twiitti 18.2.2020)

Yliopisto reagoi kohuun twiittaamalla pahoittelunsa iltapäivällä 18. helmikuuta. Rehtori Wallsin omalta tililtä lähetetyssä viestissä oli lisäksi hymiöillä koristeltu varsin maltillinen muunnelma tuninaamasta epävarmuutta korostavalla saatteella:

Pyysimme opiskelijajärjestö Vivaa poistamaan yliopiston logomuunnoksen heidän julisteistaan ja verkkosivuiltaan saamamme palautteen perusteella. Reagointimme oli liian jyrkkä ja pahoittelemme sitä. Tarkoituksena ei ole kieltää satiiria tai meemien käyttöä. \#tuninaama (@TampereUni, twiitti 18.2.2020)

Meillä @TampereUni on upea Q \#inhimillinen \#tuninaama logo. Taipuu moneen \#filikseen / Tässä \#ystäväni versio jakoon :) Kun olo on vielä ensiaskeleilla \#epävarma - kuten uudessa \#fuusio \#yliopisto'ssa - \#itseironia on vaikea laji. Ymmärrätte varmaan... \#ihminenratkaisee (@mariwalls, twiitti 18.2.2020)

Rehtorin viesti edustaa pragmaattisen legitimiteetin varmistamiseen tähtäävää mukauttamisen strategiaa, jolla pyritään ottamaan sidosryhmän näkökulmat paremmin huomioon. Vuoropuhelu kuitenkin jatkuu, ja verkkokeskustelijat irvailevat takaisin, että logomuunnokset ja kritiikki ovat vain nostaneet TUNI-brändin tunnettuutta:

@TampereUni Älkää nyt helvetissä pahoitelko. Takokaa, rauta on kuumaa. Ennen tätä olin vallan unohtanut että Tampereella on yliopisto. (twiitti 19.2.2020)

@TampereUni Brändinne on todellakin... tuota, vahvistunut tässä viime aikoina. (twiitti 18.2.2020)

Vaikka tuninaaman ympärillä käyty keskustelu on pääasiassa parodista ilottelua, joka osaltaan myös tukee pragmaattista legitimiteettiä, se kääntyy pian takaisin vakaviin, delegitimoiviin teemoihin: henkilöstön puutteelliseksi koettuun edustukseen yliopiston hallinnossa, tietojärjestelmäuudistuksiin, organisaatiouudistukseen ja rehtorivalinnassa salattuihin dokumentteihin. Vivan Ilona Taubert (2020b) perustelee pitkässä Twitter-ketjussa 19. helmikuuta, mitä organisaatiouudistukseen liittyviä kipukohtia logoparodioiden taustalla on. Näin akateeminen yhteisö onnistuu kääntämään huumoripitoisen keskustelun takaisin legitimiteettiin liittyviin keskeisiin asiakysymyksiin.

Tuninaaman tai \#tuninaaman käyttö sosiaalisen median julkaisuissa asemoi ne monipuolisesti eri huumorilajien keinoja käyttäviksi kriittisiksi puheenvuoroiksi, joiden kautta uuden yliopiston syntyyn liittyvää epävarmuutta pyrittiin purkamaan luovilla ja yhteisöllisyyttä vahvistavilla tavoilla. Bitektinen ja Haackin (2015) termein näissä twiiteissä virallista auktoriteettiasemaa vailla olevat toimijat pääsevät tekemään legitimaatioarviointia diskursiivisen ja symbolisen toiminnan kautta: 
Olisitte tyytyväisiä siitä että me välitetään tästä yliopistosta vielä niin paljon että jaksamme kritisoida. Välinpitämättömyys yliopistoa on pahinta mitä voisi tapahtua.

(@llonaTaubert, ketju 19.2.2020)

Näiden käytäntöjen valossa @TampereUni ei täytä Magna Charta Universitatumin henkeä ja arvoja. Pitäisikö vakavasti harkita tämän oppilaitoksen uudelleen määrittelemistä ammattikorkeakouluksi (University of Applied Sciences)? (twiitti 20.2.2020)

Maaliskuun alussa 2020 Tampereen yliopiston viestintä- ja brändijohtajan työsuhde päätettiin yllättäen, mikä inspiroi sosiaalisen median kommentaattoreita entistä kärkevämpään viestintään. Seuraavassa esimerkissä (kuva 2) viestintä- ja brändijohtajaa symboloivan Tuninaamio-hahmon ja \#tuninaama-tunnisteen kautta tarkastellaan ironisesti yliopiston brändityön käytäntöjä:

Kuva 2. Viestintä- ja brändijohtajan eroa kommentoiva kuvatwiitti (ote twiittiketjusta) nimimerkiltä Cthulhu Kimallus (6.3.2020).

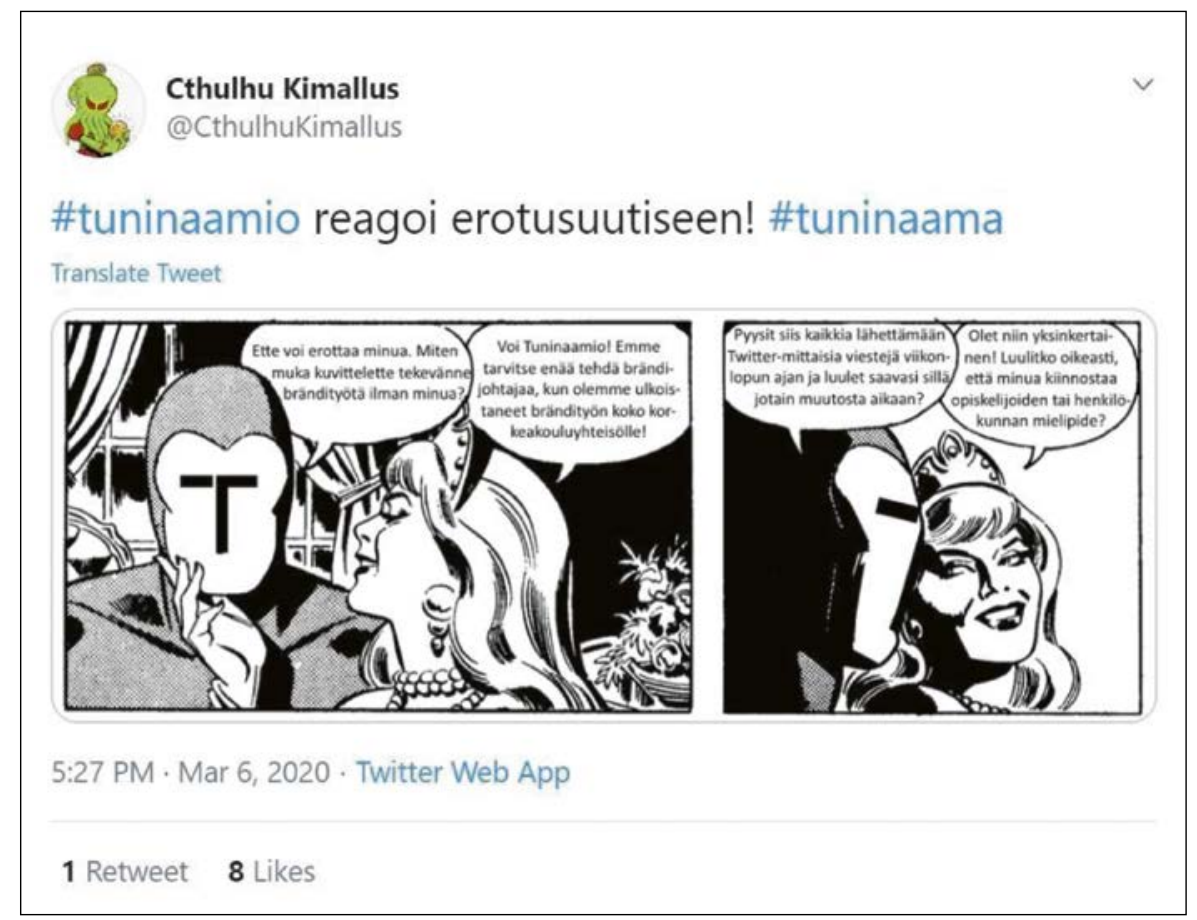

Myös tuninaamaan liittyvää kamppailua voidaan analysoida moraalisen legitimiteetin näkökulmasta ja esimerkkinä prosessilegitimiteettiin liittyvästä keskustelusta. Prosessilegitimiteetti rakentuu, kun organisaation prosessit ja työskentelytavat koetaan oikeanlaisina ja asianmukaisina. Siinä missä rehtorille, viestintäjohtajalle ja brän- 
dinrakennuksessa mukana olleelle työryhmälle tuninaamassa kiteytyy hierarkia, jossa johdon päätösten tuloksena on päädytty tiettyyn muuttumattomaan lopputulokseen (logo ja brändiväri), yliopistoyhteisölle ja erityisesti opiskelijoille tuninaama näyttäytyy ennemminkin modifikaatioihin ja ironisiin muunnelmiin kannustavana ilmeettömänä pohjana. Ristiriita syntyy siitä, että yliopiston johto, hallituksen jäsenet ja sidosryhmien edustajat ovat hyväksyneet tietyn, tarkasti määritellyn logon, mutta samalla ovi sen muuntelulle on sulkeutunut.

Tilanteessa, jossa yliopisto-organisaation legitimiteetti horjuu akateemisen yhteisön keskuudessa, logosta ja sen muuntelusta muodostuu symbolinen tapa käsitellä ilmassa olevia ristiriitoja. Yliopistoyhteisön näkökulmasta kritiikin ulottumattomiin asetetut ja hierarkkisesti ylläpidetyt "totuudet" rikkovat moraalista legitimiteettiä, koska niitä voi pitää tieteenvastaisina. Moraaliselta kannalta yliopiston toimintaa ohjaavien arvojen olisi hyvä pikemminkin korostaa ruohonjuuritason työstä nousevaa omaehtoista ajattelua ja vapaata, kriittistä keskustelua. Tuninaaman versiointi näyttäytyy yliopistoyhteisölle mahdollisuutena ja johdolle uhkana:

Yliopiston rehtori Walls selitti logon käyttökieltoon liittynyttä kohua vetoamalla siihen, että kyse on vain ensiaskeleiden epävarmuudesta fuusion keskellä. Ja kuin alleviivatakseen kritisoitua "pöhinäretoriikkaa", rehtori liitti twiittiinsä hashtagit \#ihminenratkaisee ja \#filikseen. (Vuorikoski 2020.)

Ja tätä ei korjata millään viestintähöpinälöpinällä vaan @TampereUni tulee tehdä mitä pikimmiten suunnitelma siitä, miten jatkossa jokainen henkilövalintaprosessi toteutetaan avoimuuden periaatteet huomioiden. Millään muulla tätä ei ratkaista. Loppuun ironinen \#ihminenratkaisee (twiitti 13.2.2020)

Tämä @tampereuni meininki vaikuttaa kaiken kaikkiaan siltä, että siellä ei ole otettu huomioon mitenkään sitä, miten yliopisto voisi näyttäytyä houkuttelevana vaihtoehtona yhteiskuntatieteilijälle. [linkki SK:n juttuun] (twiitti 13.2.2020)

Kiinnostavasti tuninaama-aihetunnisteesta ja -termistä muodostuu kuitenkin lopulta yhteisöllisyyden symboli Twitter-keskustelijoille. Ensimmäisiä merkkejä tästä näkyy jo helmikuun lopulla, mutta erityisesti koronaviruksen aiheuttaman poikkeustilan alkaessa maaliskuun puolivälin tienoilla tuninaamat muuttuvatkin Tampereen yliopiston edustajiksi, jotka yhdessä selviävät kriisistä:

@käyttäjä @TampereUni Kyllä! Parastahan on just ne kaikki \#tuninaama:t joiden kanssa saa tehdä duunia, jakaa kahvihuoneen ja kuulua samaan yliopistoyhteisöön. \#Ihminenratkaisee, indeed! (twiitti 19.2.2020)

vielä vähän \#tuninaamakohu:sta: "Kolkko tuninaama on paljon elävämmän oloinen nyt, kun se on seikkaillut sadoissa meemikuvissa edustamassa Tampereen korkeakouluja." [linkki blogikirjoitukseen] (twiitti 2.3.2020) 
Maaliskuun alussa vaikuttaa viimein siltä, että yliopiston johto reagoi verkossa ja mediassa käytyyn kriittiseen keskusteluun myös pöhinäretoriikan ja brändipuheen osalta. 26. helmikuuta Suomen Kuvalehdessä julkaistu Herlinin haastattelu (KeskiHeikkilä 2020b) saa Twitterissä kiitoksia. Herlin myös viittasi haastattelussa tuleviin muutoksiin. Niinpä 4.3. Aamulehti (Sainio 2020) ja Yle (Nieminen Elina 2020) kertoivat, että viestintä- ja brändijohtaja Camilla Lindforsin työsuhde oli päätetty ja hänen eronsa astui voimaan välittömästi. Twitterissä Lindforsin eroa tosin kommentoitiin lähinnä tyytymättömin äänenpainoin: yhden henkilön lähdön ei koettu korjaavan strategiaa tai tehtyjä linjauksia, ja ero koettiin yritykseksi pelastaa tilanne näyttävästi. Samaan aikaan Twitterissä kerättiin nimiä opiskelijoiden ja henkilökunnan yhteiseen vetoomukseen sekä hämmästeltiin yliopistoa kritisoimaan ilmestyneen Kaski Agencyn konsultin toimintaa (ks. Mikkonen 2020). Ruohonjuuritason toimijat siis pyrkivät yhteistyössä asemaan, josta he voivat yhdessä vahvemmin validoida yliopiston legitimiteettiä.

Aineistomme viimeinen keskustelupiikki nousee perjantaina 6. maaliskuuta, kun rehtori Mari Walls lähettää koko henkilöstölle ja opiskelijoille sähköpostikutsun osallistua yliopiston brändin kommentointiin ja yhteiskehittämiseen lomakekyselyn avulla (ks. Cthulhu Kimallus 2020). Aikaa vastauksille annettiin aluksi maanantaihin 9.3. asti, mutta vastausaikaa pidennettiin kriittisen palautteen perusteella keskiviikkoon 11.3. saakka. Brändistä ja viestinnästä käytiin kyselyn innoittamana runsaasti keskustelua \#tuninaama-tunnisteen alla. Kommentoijat olivat toisaalta tyytyväisiä johdon reagointiin ja mukauttamisen strategian käyttöön legitimiteetin tukemiseksi, mutta kyselyn aikataulu nostatti kriittisen keskustelun jälleen uusille kierroksille (ks. esimerkit ja kuva 3):

@TampereUni rehtori kutsuu yhteisön yhteiskehittämään brändiä ja brändiviestintää verkkokyselyllä. Ensimmäisen vaiheen kerrotaan olevan auki kolme päivää ja se alkoi näin perjantaina iltapäivällä. Kivaa, että kehitetään, mutta miksi näin kiireinen prosessi? \#tampereuni (twiitti 6.3.2020)

@käyttäjä @TampereUni @_mariwalls No kun siellä on sytytelty niitä intohimoisia tulipaloja, niin onhan ne nopeasti sammutettava ennenkuin koko yliopisto kärventyy luovuuteensa? (twiitti 6.3.2020) 
Kuva 3. Twiittireaktio brändikyselyyn 8.3.2020 (Nieminen Esko 2020).

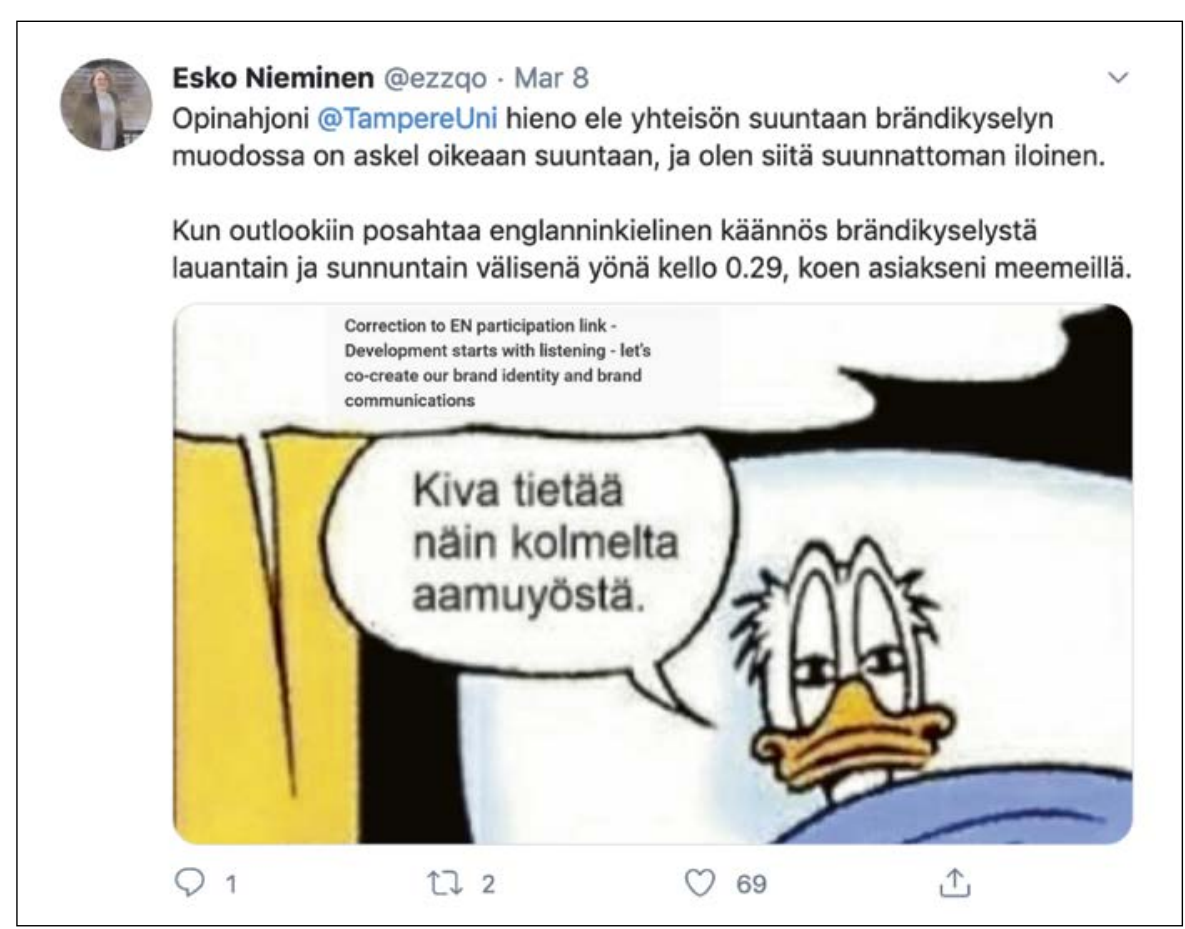

Jo saman päivän iltana (6.3.) rehtori Mari Walls, jälleen pragmaattisen legitimiteetin rakentamiseksi käytettyä mukauttamisen strategiaa noudattaen, lähetti yliopistolaisille sähköpostiviestin, jossa hän pyysi anteeksi:

Brändimme ja brändiviestintämme on herättänyt yhteisössämme ja myös julkisuudessa paljon keskustelua. Olen erittäin pahoillani siitä, ettemme ole johdossa onnistuneet luomaan kaikille edellytyksiä kokea aidosti kuuluvansa uuteen korkeakouluyhteisöön. (ks.

Cthulhu Kimallus 2020.)

Sähköpostiviestinnän mukaan brändiä ryhdyttiin kehittämään. Yhteisön jäseniä kehotettiin osallistumaan työhön vastaamalla kyselyyn ja kertomalla muun muassa, millainen brändi ja brändiviestintä tukisi parhaiten Tampereen yliopiston tutkimusta, koulutusta ja yhteiskunnallista vaikuttavuutta. (Paananen 2020.) Näin pyrittiin aktivoimaan yliopistolaisia ja kenties ainakin luomaan vaikutelma siitä, että organisaation toimintaa pyritään viemään sidosryhmien toiveiden suuntaan. 


\section{Keskustelu ja yhteenveto}

Tässä artikkelissa analysoimme Tampereen yliopiston organisaatiouudistukseen ja erityisesti sen uuteen brändi- ja viestintästrategiaan kytkeytyviä legitimiteettikamppailuja hybridissä mediatilassa. Analyysimme eri mediamuodoissa esiintyvistä legitimiteetin arvioista osoittaa, miten mediatilan monimuotoistuminen tuottaa ongelmia monikohteiselle sidosryhmäviestinnälle, jossa organisaation legitimiteettiä pyritään muutostilanteessa rakentamaan. Tarkastelemamme tapaus kuvaa sitä, miten hankittu ja koettu kognitiivinen legitimiteetti murentuu ja muuntuu organisaation muutostilanteessa moraalisen legitimiteetin kiistoiksi, joita käydään diskursiivisesti julkisuudessa. Kun organisaation identiteetin ja sen tuottaman viestinnän välillä on ristiriita sidosryhmän - tässä tapauksessa erityisesti yliopistoyhteisön - näkökulmasta, hybridi mediatila mahdollistaa kriittisten äänien nousun merkittäväksi delegitimoivaksi voimaksi. Näin tapahtuu erityisesti silloin, kun äänessä ovat tyypillisesti legitimaatiota organisaatiolle vahvistavat työntekijät.

Artikkelimme osallistuu keskusteluun korostamalla legitimiteetin käsitteen merkitystä, kun tuotetaan tulkintoja ja ymmärrystä siitä, miten ja miksi organisaation johdon ja sisäisten sidosryhmien välinen keskustelu muutoksesta leviää organisaation ulkopuoliseksi, hybridiksi mediatapahtumaksi. Aiemmassa legitimiteettitutkimuksessa (esim. Vaara \& Tienari 2008; Suddaby \& Greenwood 2005) on paljolti keskitytty organisaatioiden omaan legitimaatiota rakentavaan viestintään erityisesti diskursiivisen legitimaation (Van Leeuwen 2007) kautta. Tässä artikkelissa olemme lähestyneet ilmiötä mediajulkisuuden ja sosiaalisen median keskustelujen kautta ja tuoneet näin aiheeseen toisen näkökulman. Tampereen yliopiston legitimiteettiä koskevissa keskusteluissa sekoittuvat sosiaalinen ja moraalinen arviointi: se siirtyy yksilön arvioimasta kognitiivisesta legitimiteetistä sosiopoliittisen arvioinnin piiriin (Bitektine 2011; Tost 2011). Pelkästään se, että kyseessä on yliopisto, ei enää riitä tukemaan Tampereen yliopiston legitimiteettiä, ja sidosryhmä alkaa kyseenalaistaa organisaation olemassaolon oikeutusta. Äärimmäisissä tapauksissa pohdinnat isäntäorganisaation hyödyllisyydestä tai vaarallisuudesta arvioivalle yksilölle tai yhteiskunnalle (Bitektine 2011) johtavat konkreettisiin tekoihin: esimerkiksi eräs Twitterissä aktiivisesti keskustellut apurahatutkija kertoi julkisesti, ettei halunnut uusia affiliaatiotaan.

Analyysimme perusteella hybridin mediatilan eri mediat ja alustat tuottavat ja haastavat legitimiteettiä eri tavoin. Journalistisessa mediassa keskeisiksi nousevat isot tapahtumien kaaret ja kiistat, jotka istuvat helposti uutiskriteereihin. Tällainen oli esimerkiksi rehtorin tehtävään hakeneiden henkilöllisyyden salaaminen yliopiston hakijoille antamalla ohjeistuksella. Yhtäältä journalismia rakennetaan yleisen henkilöitymiskehityksen ohjaamana mielellään kuuluisilta ja arvovaltaisilta henkilöiltä saatavien sitaattien varaan (ks. esim. OKM:n kansliapäällikön Anita Lehikoisen haastattelu Suomen Kuvalehdessä, Niemelä 2018). Toisaalta aineistossamme ovat myös yliopistoa delegitimoivat keskeisten henkilöiden esittämät näkökannat hyvin edustettuina. 
Ylipäätään journalistisessa mediassa ääneen pääsevät merkittävät, jo valmiiksi valta-asemassa olevat toimijat kuten yliopiston rehtori, hallituksen puheenjohtaja ja professorit. Sosiaalisen median areenalla, tässä tapauksessa Twitterissä, äänessä ovat yliopistoyhteisön edustajat: henkilökunta, apurahatutkijat ja opiskelijat. Tällä areenalla eriävien mielipiteiden esittämisen kynnys on matalampi kuin yliopiston sisällä tai journalistisessa mediassa (ks. Bitektine \& Haack 2016, 62). Verkosta kritiikki nousee toisinaan myös journalismiin; esimerkiksi yliopistonlehtori Hakkaraisen vetoomus päätyi myös Suomen Kuvalehden sivuille (Keski-Heikkilä 2020a), ja Nyt-liite (Körkkö 2020) koosti jutun tuninaaman parodioista. Tällaisesta mediamuotojen välisestä vuorovaikutuksesta on kirjoitettu paljon jo aiemmassa tutkimuksessa (esim. Laaksonen 2017; Sumiala ym. 2018; Arjoranta ym. 2017). Analyysimme osoittaa, että sama logiikka pätee myös legitimaatiokamppailussa: journalistinen media tuottaa lisänäkyvyyttä tietyille sosiaalisen median toimijoille.

Pysyvin legitimiteetin muoto on kognitiivinen legitimiteetti. Jos yliopisto olisi jatkanut edeltäjiensä Tampereen yliopiston ja Tampereen teknillisen yliopiston viitoittamalla tiellä muuttaen viestintästrategiaansa mahdollisimman vähän, yliopiston henkilöstölle ja opiskelijoille ei olisi juurikaan tarvinnut tuottaa erikseen legitimoivaa viestintää. Heidän osaltaan olisi ulkoisen legitimaatiokamppailun sijasta voitu keskittyä siihen, miten erilaisista toimintatavoista päästään siirtymään yhteisiin, ja legitimiteetti olisi rakentunut ymmärrettävyydestä - siitä että yliopisto toimii kulttuuristen perinteiden ja mallien pohjalta kuten ennenkin (vrt. Suchman 1995, 582-583; Aula ym. 2015). Erityisesti tätä tutkimusta varten kerätyn aineiston alkupuolella vaikuttaa siltä, että tilaa mielipiteen ilmaisulle ei ole Tampereen yliopiston sisällä annettu ennen maaliskuun yleistä brändikyselyä. Siksi kritiikki näyttää etsiytyneen muille areenoille. Kiinnostavaa on, että vaikka keskustelua pöhinäretoriikasta ja brändistrategiasta oli käyty Twitterissä jo tammikuusta alkaen, Tampereen yliopisto koki tarpeelliseksi puuttua asiaan vasta helmikuussa tuninaamamuunnosten noustua pinnalle ja keskustelun sävyn muututtua parodiseksi ja ivalliseksi.

Julkisuuteen nousevat legitimaatiokamppailut heijastelevat sitä, että sekä uuden yliopiston organisaatio että sen tapa viestiä itsestään ovat muuttuneet. Uusi viestintätyyli on vahvasti ristiriidassa yliopistoyhteisön organisaatiokäsityksen kanssa ja murentaa siksi sen legitimiteettiä (vrt. Tost 2011). Oman viestintäyksikön motiiveja ja tarvetta rakentaa uuden yliopiston legitimiteettiä mukauttamisen ja jopa manipulaation kautta on henkilöstön kognitiivisen legitimiteettikokemuksen näkökulmasta vaikea ymmärtää, paitsi jos hyväksymme lähtökohdaksi sen, että uuteen siirryttäessä myös viestinnän perinpohjaiselle uudistamiselle on johdossa nähty selvä tarve. Ulkopuolisten konsulttien, viestintäjohtajan ja kenties myös säätiöyliopiston hallituksen toimeksianto on ollut rakentaa uutta brändiä. Tämän he ovat tehneet yritysmaailmassa legitiimeinä ja itsestäänselvinä pidettyjen arvojen ja toimintatapojen mukaisesti. Ne eivät kuitenkaan sellaisinaan ota huomioon yliopiston statusta ja erityislaatuisuutta. Ristiriita on näin ollen ollut valmis (vrt. Aula ym. 2015). 
Artikkelissamme olemme pohtineet yliopisto-organisaation erityisluonteeseen liittyviä legitimiteettikamppailuja ja valottaneet niitä legitimoinnin ja delegitimoinnin julkisen rakentumisen näkökulmasta. Kuuselan ja kumppaneiden $(2019,18)$ raportissa todettu ristiriita yhteisön sisäisten yliopistodemokratiasta lähtevien arvojen ja yliopiston managerialististen johtamistapojen välillä näyttäytyy legitimiteetin käsitteen valossa yhtenä merkkinä laajemmasta yhteiskunnallisten arvostusten kohtaamattomuudesta. Kun eri toimijat ovat lähteneet omista kognitiivisesti legitiimeinä pitämistään itsestäänselvyyksistä, on syntynyt tilanteita, joissa esimerkiksi viestinnän tyyli on toisella puolella näyttäytynyt uudelta, raikkaalta ja eteenpäin vievältä ja toisella puolella naurettavalta tai surkuhupaisalta.

Yliopiston legitimiteetti on monilta osin itsestään selvä asia. Kuten Tampereen yliopiston innovaatiojohtaja Taru Pilvi totesi Kauppalehden sponsoroidussa julkaisussa 20. helmikuuta 2020: "Yliopisto on luovien, itseohjautuvien ja intohimoisesti alaansa suhtautuvien ihmisten yhteisö." Tästä näkökulmasta tarkasteltuna delegitimoiva julkinen keskustelu ja journalistiset valinnat ovat voineet tulla monelle yllätyksinä. Muutostilanteissa johdolta odotetaan herkkyyttä tunnistaa organisaatiossa vallitsevat arvot ja periaatteet. Jos tätä ei johdossa huomata, eikä keskustelua organisaation sisällä mahdollisteta vaan pikemminkin hillitään, opiskelijoiden ja henkilöstön ääni siirtyy helposti mediatilan uusille institutionalisoituneille areenoille (vrt. Cassinger \& Thelander 2020). Näillä viestintätapahtumat ovat lopulta aina hallitsemattomia, vaikka viestintää pyrittäisiin kaikin keinoin pitämään institutionaalisessa kontrollissa (vrt. Poutanen \& Laaksonen 2020, 82). Esimerkki viestinnän hallitsemattomuudesta on brändäyksessä käytetty metafora tulipalojen sytyttämisestä rajapinnoille. Sen tarkoitus on ollut välittää kuvaa muutoksesta, jossa mennään innolla yhdessä kohti uutta. Metaforien tapaan se alkaa kuitenkin elää omaa elämäänsä (ks. Piata 2016) ja päätyy viittaamaan innovaatiotoiminnan asemasta Tampereen yliopiston viestinnällisiin epäonnistumisiin. Niin hyödyllisiä kuin metaforat yritysviestinnässä ovatkin, niihin liittyy hybridissä mediatilassa suuri riski päätyä ivailevien meemien rakennusaineeksi.

\section{Kirjallisuus}

Ainiala, Terhi; Räisä, Tiina \& Sjöblom, Paula (2020). Mediakeskustelun välittämä. Tampereen yliopiston nimenvalintaprosessi osallistujien roolien, positioiden ja argumenttien valossa. Puhe ja kieli 40:1, 1-22. https://doi.org/10.23997/pk.95494

Alasuutari, Pertti (2018). Akatemiaprofessori kypsyi Tampereen yliopistoon: "En ole varma, haluanko jatkaa uraani täällä". Mielipidekirjoitus, Suomen Kuvalehti 7.6.2018. Saatavilla: https://suomenkuvalehti.fi/jutut/kotimaa/mielipide-kotimaa/akatemiaprofessori-kypsyitampereen-yliopistoon-en-ole-varma-haluanko-jatkaa-uraani-taalla/ (luettu 30.11.2020).

Anttila, Jaakko (2020). Ihminen logonaamion alla - Tampereen yliopiston todelliset kasvot. Vita Nuova -blogi 1.3.2020. Saatavilla: https://vitanuovablogi.wordpress.com/2020/03/o1/ihminenlogonaamion-alla-tampereen-yliopiston-todelliset-kasvot/ (luettu 30.11.2020).

Arjoranta, Jonne; Hirsjärvi, Irma; Kovala, Urpo; Saresma, Tuija \& Ruotsalainen, Maria (2017). Turvetta tupaan: faktat, valheet ja affektiivinen vastaanotto Turveinfo-mainoskampanjassa. Media $Q$ viestintä 40:3-4. https://doi.org/10.23983/mv.67795

Aula, Hanna-Mari; Tienari, Janne \& Wæraas, Arild (2015). The University Branding Game. Players, Interests, Politics. International Studies of Management Q Organization 45:2, 164-179. https://doi.org/10.1080/00208825.2015.1006015 
Berger, Peter L. \& Luckman, Thomas (1966). The social construction of knowledge. New York: Doubleday.

Bitektine, Alex (2011). Toward a Theory of Social Judgments of Organizations: The Case of Legitimacy, Reputation, and Status. Academy of Management Review 36:1, 151-79. https://doi.org/10.5465/amr.2009.0382

Bitektine, Alex \& Haack, Patrick (2015). The 'Macro' and the 'Micro' of Legitimacy: Toward a Multilevel Theory of the Legitimacy Process. Academy of Management Review 40:1, 49-75. https://doi.org/10.5465/amr.2013.0318

Cassinger, Cecilia \& Thelander, Åsa (2020). Voicing the Organization on Instagram: Towards a Performative Understanding of Employee Voice. Public Relations Inquiry 9:2, 195-212. https://doi.org/10.1177/2046147×20920820

Chadwick, Andrew (2013). The Hybrid Media System. Politics and Power. Oxford: Oxford University Press.

Chapleo, Chris (2011). Exploring rationales for branding a university: Should we be seeking to measure branding in UK universities? Journal of Brand Management 18:6, 411-422. https://doi.org/10.1057/bm.2010.53

Chapleo, Chris; Durán, María Victoria Carrillo \& Díaz, Ana Castillo (2011). Do UK universities communicate their brands effectively through their websites? Journal of Marketing for Higher Education 21:1, 25-46. https://doi.org/10.1080/08841241.2011.569589

Cthulhu Kimallus (2020). Twiitti 6.3.2020. Saatavilla: https://twitter.com/CthulhuKimallus/ status/1235950115627642881 (luettu 30.11.2020).

Davis, Aeron (2013). Promotional Cultures: The Rise and Spread of Advertising, Public Relations, Marketing and Branding. Cambridge, UK: Polity Press.

Dean, Dianne; Arroyo-Gamez, Ramon E.; Punjaisri, Khanyapuss \& Pich, Christopher (2016). Internal brand co-creation: The experiential brand meaning cycle in higher education. Journal of Business Research 69:8, 3041-3048. https://doi.org/10.1016/j.jbusres.2016.01.019

Deephouse, David L. \& Carter, Suzanne M. (2005). An Examination of Differences Between Organizational Legitimacy and Organizational Reputation. Journal of Management Studies 42:2, 329-36o. https://doi.org/10.1111/j.1467-6486.2005.00499.x

Deephouse, David \& Suchman, Mark (2008). Legitimacy in Organizational Institutionalism. Teoksessa: Greenwood, Royston; Oliver, Christine; Lawrence, Thomas B. \& Meyer, Renate E. (toim.). The Sage Handbook of Organizational Institutionalism. London \& Thousand Oaks: Sage, 49-77. https://doi.org/10.4135/9781849200387.n2

Drori, Israel \& Honig, Benson (2013). A Process Model of Internal and External Legitimacy. Organization Studies 34:3, 345-76. https://doi.org/10.1177/0170840612467153

Fairclough, Norman (2003). Analysing discourse. Textual analysis for social research. New York: Routledge.

Fitzgerald, Joseph \& O'Rourke, Brendan (2016). Legitimising expertise: analysing the legitimation strategies used by economics experts in broadcast interviews. Journal of Multicultural Discourses 11:3, 269-282. https://doi.org/10.1080/17447143.2016.1218889

Furedi, Frank (2010). Introduction to the marketisation of higher education and the student as consumer. Teoksessa: Molesworth, Mike; Scullion, Richard \& Nixon, Elizabeth (toim.). The Marketisation of Higher Education and the Student as Consumer. London \& New York: Routledge, 1-7. https://doi.org/10.4324/9780203842829

Galtung, Johan \& Ruge, Mari H. (1965). The structure of foreign news. Journal of Peace Research 2, 64-91.

Grönholm, Pauliina (2019). Riitaa oli nimestä, rahasta, rehtorista ja johtosäännöstä, mutta nyt Tampereella alkoi uuden jättiyliopiston ensimmäinen lukukausi. Helsingin Sanomat 26.8.2019. Saatavilla: https://www.hs.fi/kotimaa/art-2000006216210.html (luettu 30.11.2020).

Haack, P., Pfarrer, M. D., \& Scherer, A. G. (2014). Legitimacy-as-feeling: How affect leads to vertical legitimacy spillovers in transnational governance. Journal of Management Studies 51:4, 634-666.

Harju, Jukka (2018). Kriisikokous Tampereen yliopistolla, työntekijät aikovat marssia ulos - "Väki oli täysin päättäväistä, että meidän ylitsemme ei kävellä". Helsingin Sanomat 6.2.2018. Saatavilla: https://www.hs.fi/kotimaa/art-2000005554934.html (luettu 30.11.2020).

Harju, Jukka (2020). SK: Tampereen yliopisto kätki rehtorihakijoiden paperit, oikeusoppinut arvostelee toimintaa. Helsingin Sanomat 13.2.2020. Saatavilla: https://www.hs.fi/kotimaa/art2000006406643.html (luettu 30.11.2020).

Hämeen-Anttila, Jaakko (2018). Tampereen yliopistoa valjastetaan yritysmaailman käskyläiseksi. Kolumni Helsingin Sanomat 18.6.2018. Saatavilla: https://www.hs.fi/kotimaa/art-2000005724086. html (luettu 30.11.2020). 
Jalonen, Jussi (2018). "Wau!"-akatemia. Historiantutkijan näkötorni -blogi 24.11.2018. Saatavilla: https://jojalonen.wordpress.com/2018/11/24/wau-akatemia/ (luettu 30.11.2020).

Jessop, Bob (2017). Varieties of academic capitalism and entrepreneurial universities. Higher Education 73:6, 853-870. https://doi.org/10.1007/s10734-017-0120-6

Joutsenvirta, Maria \& Vaara, Eero (2015). Legitimacy Struggles and Political Corporate Social Responsibility in International Settings: A Comparative Discursive Analysis of a Contested Investment in Latin America. Organization Studies 36:6, 741-77. https://doi.org/10.1177/0170840615571958

Joutsenvirta, Maria \& Vaara, Eero (2009). Discursive (de)Legitimation of a Contested Finnish Greenfield Investment Project in Latin America. Scandinavian Journal of Management 25:1, 85-96. https://doi.org/10.1016/j.scaman.2008.11.002

Junkkari, Marko (2018). Olisin ollut käytettävissä. Helsingin Sanomat 16.12.2018. Saatavilla: https://www.hs.fi/sunnuntai/art-2000005932575.html (luettu 30.11.2020).

Keski-Heikkilä, Anni (2020a). "Pöhinäretoriikka lopetettava" - Tampereen yliopiston väki turhautui viestintään, nimiä kerätään vetoomukseen. Suomen Kuvalehti 20.2.2020. Saatavilla: https://suomenkuvalehti.fi/jutut/kotimaa/pohinaretoriikka-lopetettava-tampereen-yliopiston-vakiturhautui-viestintaan-nimia-kerataan-vetoomukseen/ (luettu 30.11.2020).

Keski-Heikkilä, Anni (2020b). Maailmojen törmäys. Suomen Kuvalehti 26.2.2020. Saatavilla: https://suomenkuvalehti.fi/jutut/kotimaa/nyt-pohinaretoriikasta-puhuu-tampereen-yliopistonhallitusta-johtava-herlin-jos-linja-ei-muutu-siita-tulee-hallitusasia/ (luettu 30.11.2020).

Kolbe, Laura (2012). "Huipulle ja yhteiskuntaan" - oma kulttuuriperintö yliopistojen kilpailuvaltiksi. Tieteessä Tapahtuu 30:4. Saatavilla: https://journal.fi/tt/article/view/6502 (luettu 30.11.2020).

Korpela, Jukka \& Nevala, Arto (2020). Minne menet yliopisto ja kuka sinua vie? Tieteessä Tapahtuu 38:4, 44-50. Saatavilla: https://journal.fi/tt/article/view/98135 (luettu 30.11.2020).

Koskela, Merja \& Sihvonen, Tanja (2018). \#Hashtagin funktiot Twitterissä. Aihetunniste metadatana, erikoiskielenä ja luovuuden välineenä. Isotalus, Pekka; Jussila, Jari \& Matikainen, Janne (toim.) Twitter viestintänä. IImiöt ja verkostot. Tampere: Vastapaino, 31-50.

Kosonen, Miia; Rydenfelt, Henrik; Laaksonen, Salla-Maaria \& Terkamo-Moisio, Anja (2018). Sosiaalinen media ja tutkijan etiikka. Media Q viestintä 41:1. https://doi.org/10.23983/mv.69924

Kuusela, Hanna; Harju, Auli; Kaleva, Veera; Poutanen, Mikko; Raipola, Juha; Tervasmäki, Tuomas \& Tomperi, Tuukka. (2019). Kenen yliopisto? Tampereen yliopiston henkilöstön näkemyksiä yliopistojen johtamisjärjestelmistä ja itsehallinnosta. Comet, Tampereen yliopisto. Saatavilla: https://trepo.tuni.fi/handle/10024/117081 (luettu 30.11.2020).

Körkkö, Hilla (2020). Tampereen yliopisto "uhitteli" sen logoa muokannutta opiskelijaa tavaramerkkilain rikkomisella - Nyt somessa leviää mitä erilaisempia versioita "tuninaamasta". Nyt 18.2.2020. Saatavilla https://www.hs.fi/nyt/art-2000006411713.html (luettu 30.11.2020).

Laaksonen, Salla-Maaria (2017). Hybrid Narratives - Organizational Reputation in the Hybrid Media System. Väitöskirja. Publications of the Faculty of Social Sciences, Media and Communication Studies 53/2017. Saatavilla: http://urn.fi/URN:ISBN:978-951-51-2612-2 (luettu 30.11.2020).

Lattu, Annina (2020). Tutkijayrittäjyyden inho ja kapitalismin puutteet. Tieteessä tapahtuu 4, 41-44. Saatavilla: https://journal.fi/tt/article/view/98127/56055 (luettu 30.11.2020).

Luoma-aho, Vilma (2005). Faith-Holders as Social Capital of Finnish Public Organisations. Väitöskirja. Jyväskylän yliopisto.

McKelvey, Karissa; DiGrazia, Joseph \& Rojas, Fabio (2014). Twitter publics: how online political communities signaled electoral outcomes in the 2010 US house election. Information, Communication Q Society 17:4, 436-450. https://doi.org/10.1080/1369118x.2014.892149

Meyer, John W. \& Scott, W. Richard (1983). Centralization and the legitimacy problems of local government. Teoksessa Meyer, John W. \& Scott, W. Richard (toim.): Organizational environments: Ritual and rationality, 199-215. Beverly Hills, CA: Sage.

Mikkonen, Heikki (2020) Twiitti 26.2.2020. Saatavilla: https://twitter.com/hemikkonen/ status/1232787051940061187 (luettu 30.11.2020).

Molesworth, Mike; Scullion, Richard \& Nixon, Elizabeth (2011). (toim.). The Marketisation of Higher Education and the Student as Consumer. London \& New York: Routledge. https://doi.org/10.1080/0267257X.2011.614734

Naidoo, Rajani \& Jamieson, Ian (2005). Knowledge in the marketplace: The global commodification of teaching and learning in higher education. Teoksessa: Ninnes, Peter \& Hellstén, Meeri (toim.). Internationalizing higher education. Dordrecht, NL: Springer, 37-51. https://doi.org/10.1007/1-4020-3784-8_3 
Niemelä, Mikko (2018). Professorin kova puheenvuoro yliopiston valtataistelusta sai ministeriön kommentoimaan: "Valitettavaa". Suomen Kuvalehti 8.6.2018. Saatavilla: https://suomenkuvalehti. fi/jutut/kotimaa/professorin-kova-puheenvuoro-yliopiston-valtataistelusta-sai-ministerionkommentoimaan-valitettavaa/ (luettu 30.11.2020).

Nieminen, Elina (2020). Tampereen yliopiston viestintä- ja brändijohtajan työsuhde on päätetty brändäyksen ympärillä useita kohuja. Yle 4.3.2020. Saatavilla: https://yle.fi/uutiset/3-11240323 (luettu 30.11.2020).

Nieminen, Esko (2020). Twiitti 8.3.2020. Saatavilla: https://twitter.com/ezzqo/ status/1236421462728138753 (luettu 30.11.2020).

Ojala, Markus; Pantti, Mervi \& Laaksonen, Salla-Maaria (2019). Networked publics as agents of accountability: Online interactions between citizens, the media and immigration officials during the European refugee crisis. New Media Q Society 21:2, 279-297. https://doi.org/10.1177/1461444818794592

OKM (2016). Yliopistolakiuudistuksen vaikutusten arviointi. Loppuraportti 30.6.2016. Opetus- ja kulttuuriministeriön julkaisuja 2016:30. Saatavilla: https://julkaisut.valtioneuvosto.fi/bitstream/ handle/10024/75416/okm30.pdf (luettu 30.11.2020).

Onninen, Oskari (2019). WAU! Suomen Kuvalehti 11.10.2019. Saatavilla: https://suomenkuvalehti.fi/ jutut/kotimaa/valtataistelu-tampereen-yliopistossa-konsultit-hehkuttavat-wau-kokemustakommunistiankyrat-kitisevat/ (luettu 30.11.2020).

Paananen, Karoliina (2020). Tampereen yliopiston mainos sai kahvin väärään kurkkuun - Itä-Suomen yliopiston akateeminen rehtori: Selvästi harhaanjohtavaa. Suomen Kuvalehti 6.3.2020. Saatavilla: https://suomenkuvalehti.fi/jutut/kotimaa/tampereen-yliopiston-mainos-sai-kahvin-vaaraankurkkuun-ita-suomen-yliopiston-akateeminen-rehtori-selvasti-harhaanjohtavaa/ (luettu 30.11.2020).

Paju, Anna (2020). Tuninaama tuli tutuksi, mutta kiitos ei kuulu brändityölle. Kansan Uutiset 19.2.2020. Saatavilla: https://www.kansanuutiset.fi/artikkeli/4217501-tuninaama-tuli-tutuksi-mutta-kiitos-eikuulu-brandityolle (luettu 30.11.2020).

Palazzo, Guido \& Scherer, Andreas (2006). Corporate Legitimacy as Deliberation: A Communicative Framework. Journal of Business Ethics 66:1, 71-88. https://doi.org/10.1007/s10551-006-9044-2

Patomäki, Heikki (2005). Yliopisto oyj. Tulosjohtamisen ongelmat - ja vaihtoehto. Helsinki: Gaudeamus.

Piata, Anna (2016). When metaphor becomes a joke: Metaphor journeys from political ads to internet memes. Journal of Pragmatics 106, 39-56. https://doi.org/10.1016/j.pragma.2016.10.003

Porttikivi, Merja (2016). Organisaatioiden diskursiivinen legitimaatio kiistelevässä mediajulkisuudessa. Väitöskirja. Aalto-yliopisto.

Poutanen, Mikko; Tomperi, Tuukka; Kuusela, Hanna; Kaleva, Veera \& Tervasmäki, Tuomas (2020). From democracy to managerialism: foundation universities as the embodiment of Finnish university policies. Journal of Education Policy. https://doi.org/10.1080/02680939.2020.1846080

Poutanen, Petro \& Laaksonen, Salla-Maaria (2020). Strateginen taistelu faktoista. Procomma Academic, 2020, 80-95.

Pringle, James \& Fritz, Samantha (2019). The university brand and social media: using data analytics to assess brand authenticity. Journal of Marketing for Higher Education 29:1, 19-44. https://doi.org/10.1080/08841241.2018.1486345

Pöyry, Essi; Laaksonen, Salla-Maaria; Kekkonen, Arto \& Pääkkönen Juho (2018). Anatomy of Viral Social Media Events. Proceedings of the 51st Hawaii International Conference on System Sciences, 2173-82. Saatavilla: https://scholarspace.manoa.hawaii.edu/bitstream/10125/5016o/1/papero273.pdf

Raipola, Juha (2019). "Ihminen ratkaisee." Instrumentaalinen humanismi Tampereen korkeakoulusäätiön brändiviestinnässä. Tiede Q Edistys 4, 298-313. Saatavilla: http://www. tiedejaedistys.fi/images/Pdf-tiedostot/T_E_4_2019_raipola.pdf (luettu 30.11.2020).

Rauschnabel, Philipp A.; Krey, Nina; Babin, Barry J. \& Ivens, Bjoern S. (2016). Brand management in higher education: The University Brand Personality Scale. Journal of Business Research 69:8, 30773086. https://doi.org/10.1016/j.jbusres.2016.01.023

Ridell, Seija (2008) Top University - downhill for humanities? Policing the Future of Higher Education in the Finnish Mainstream Media. European Educational Research Journal 7:3, 289-307. http://dx.doi.org/10.2304/eerj.2008.7.3.289

Sainio, Sari (2020). Tampereen yliopiston viestintä- ja brändijohtajan työsuhde on päätetty tänään. Aamulehti 4.3.2020. Saatavilla: https://www.aamulehti.fi/a/d6662db6-9odo-4d8a-9da289debda61850?c=1522737894164 (luettu 30.11.2020). 
Scott, William (1977). Effectiveness of organizational effectiveness studies. Teoksessa: Pennings, Johannes \& Goodman, Paul (toim.). New perspectives on organizational effectiveness. San Francisco: JosseyBass, 63-95.

Siltamäki, Tuija (2020). Twiitti 27.1.2020. Saatavilla: https://twitter.com/siltamaeki/ status/1221867554014146561 (luettu 30.11.2020).

Solin, Anna (2006). Genre ja intertekstuaalisuus. Teoksessa: Mäntynen, Anne, Shore, Susanna \& Solin, Anna (toim.). Genre - tekstilaji. Helsinki: SKS, 72-95.

Suchman, Mark C. (1995). Managing Legitimacy: Strategic and Institutional Approaches. Academy of Management Review 20:3, 571-610. https://doi.org/10.5465/amr.1995.9508080331

Suddaby, Roy \& Greenwood, Royston (2005). Rhetorical Strategies of Legitimacy. Administrative Science Quarterly 50:1, 35-67. https://doi.org/10.2189/asqu.2005.50.1.35

Sumiala, Johanna; Valaskivi, Katja; Tikka, Minttu \& Huhtamäki, Jukka (2018). Charlie Hebdo and the Circulation of Terrorist Violence in a Hybrid Media Event. Emerald Publishing. https://doi.org/10.1108/9781787148512

Talouselämä (2018). "Tässä on huikea onnistumisen mahdollisuus" - Mari Walls on uuden Tampereen yliopiston ensimmäisen rehtori. Talouselämä 16.8.2018. Saatavilla: https://www.talouselama.fi/ uutiset/tassa-on-huikea-onnistumisen-mahdollisuus-mari-walls-on-uuden-tampereen-yliopistonensimmaisen-rehtori/9boo4fa4-4ad9-346a-af34-c43581416130 (luettu 30.11.2020).

Tampereen korkeakouluyhteisö (2020). Innovaatioiden uusi aikakausi: "Sytytämme pieniä tulipaloja tieteen rajapinnoille". Kauppalehti Studio 22.1.2020. Saatavilla: https://studio.kauppalehti. fi/studiovieras/tuni-innovaatioiden-uusi-aikakausi-sytytamme-pienia-tulipaloja-tieteenrajapinnoille?fbclid=IWAR3P1X-Vbo2wAAN5_7GogbzKmwm18U24gy1RsajTQ3dzDW8ahNjCkQICAKw (luettu 30.11.2020).

Taubert, Ilona (2018). Kannanotto: Tampereen Yliopiston hallitus riippumattomaksi Suurten Muinaisten opein. Tampereen yliopiston vihreä vasemmisto -blogi 14.6.2018. Saatavilla: https:// vihreavasemmisto.wordpress.com/2018/o6/14/kannanotto-tampereen-yliopiston-hallitusriippumattomaksi-suurten-muinaisten-opein/ (luettu 30.11.2020).

Taubert, Ilona (2020a). Avoin kirje Tampereen yliopistolle: antakaa yhteisön pilailla ilman pelkoa oikeustaistelusta. Tampereen yliopiston vihreä vasemmisto -blogi 18.2.2020. Saatavilla: https:// vihreavasemmisto.wordpress.com/2020/02/18/avoin-kirje-tampereen-yliopistolle-antakaayhteison-pilailla-ilman-pelkoa-oikeustaistelusta/ (luettu 30.11.2020).

Taubert, Ilona (2020b). Twitter-ketju 19.2.2020. Saatavilla: https://twitter.com/IlonaTaubert/ status/1230063825715593217 (luettu 30.11.2020).

Tirronen, Jarkko (2014). Suuret haasteet ja yliopiston strategiset valinnat. Tieteessä tapahtuu 32:4, 17-23. Saatavilla: https://journal.fi/tt/article/download/46150/12274 (luettu 30.11.2020).

Tost, Leigh (2011). An Integrative Model of Legitimacy Judgements. Academy of Management Review 38:4, 686-710.

Vaara, Eero \& Tienari, Janne (2002). Justification, Legitimization and Naturalization of Mergers and Acquisitions: A Critical Discourse Analysis of Media Text. Organization 9: 2, 275-304. https://doi.org/10.1177/1350508402009002912

Vaara, Eero \& Tienari, Janne (2008). A Discursive Perspective on Legitimation Strategies in Multinational Corporations. Academy of Management Review 33:4, 985-93.

https://doi.org/10.5465/amr.2008.34422019

Vaara, Eero; Tienari, Janne \& Laurila, Juha (2006). Pulp and Paper Fiction: On the Discursive Legitimation of Global Industrial Restructuring. Organization Studies 27:6, 789-813. https://doi.org/10.1177/0170840606061071

Valkama, Mikko; Puhakka, Jaakko; Takala, Jarmo \& Vuorinen, Jyrki (2018). Tampereen uuden yliopiston hallinto kuohuttaa - Neljä professoria: Emme ole yritysten käskyläisiä. Suomen Kuvalehti Mielipide 27.6.2018. Saatavilla: https://suomenkuvalehti.fi/jutut/kotimaa/mielipide-kotimaa/tampereenuuden-yliopiston-hallinto-kuohuttaa-nelja-professoria-emme-ole-yritysten-kaskylaisia/ (luettu 30.11.2020).

Van Leeuwen, Theo (2007). Legitimation in Discourse and Communication. Discourse Q Communication 1:1, 91-112. https://doi.org/10.1177/1750481307071986.

Vuorikoski, Salla (2020). Poikkeuksellista röyhkeyttä ja venkoilua Tampereella - vaakalaudalla yliopistoinstituution uskottavuus. Suomen Kuvalehti 20.2.2020. Saatavilla: https://suomenkuvalehti. fi/vuorikoski/poikkeuksellista-royhkeytta-ja-venkoilua-tampereella-vaakalaudallayliopistoinstituution-uskottavuus/ (luettu 30.11.2020). 
Wæraas, Arild \& Solbakk, Marianne N. (2009). Defining the essence of a university: lessons from higher education branding. Higher Education 57:4, 449-462. https://doi.org/10.1007/s10734-008-9155-z

Weber, Max (1964). The Theory of Social and Economic Organization. New York: Free Press.

Woolley, Samuel C. \& Howard, Philip N. (2019). Computational Propaganda. Political Parties, Politicians and Political Manipulation on Social Media. Oxford: Oxford University Press.

Ylijoki, Oili-Helena (2020). Tiede markkinoilla. Tieteessä Tapahtuu 38:1, 1-2. Saatavilla: https://journal.fi/tt/article/view/89756 (luettu 30.11.2020).

Yrjönen, Antti (2020). Twiitti 18.2.2020. Saatavilla: https://twitter.com/anttiyr/ status/1229712965139652608/photo/1 (luettu 30.11.2020). 